\title{
Shape Memory Polyurethane and its Composites for Various Applications
}

\author{
Arvind Gupta $₫$, Anoth Maharjan and Beom Soo Kim * $*$ \\ Department of Chemical Engineering, Chungbuk National University, Cheongju, Chungbuk 28644, Korea; \\ myarvind2003@gmail.com (A.G.); kretrem8722@nate.com (A.M.) \\ * Correspondence: bskim@chungbuk.ac.kr
}

Received: 21 October 2019; Accepted: 29 October 2019; Published: 4 November 2019

\begin{abstract}
The inherent capability to deform and reform in a predefined environment is a unique property existing in shape memory polyurethane. The intrinsic shape memory ability of the polyurethane is due to the presence of macro domains of soft and hard segments in its bulk, which make this material a potential candidate for several applications. This review is focused on manifesting the applicability of shape memory polyurethane and its composites/blends in various domains, especially to human health such as shielding of electromagnetic interference, medical bandage development, bone tissue engineering, self-healing, implants development, etc. A coherent literature review highlighting the prospects of shape memory polyurethane in versatile applications has been presented.
\end{abstract}

Keywords: shape memory polyurethane; composite; biomedical application; electromagnetic interference; self-healing

\section{Introduction}

The unique capability to deform in predefined conditions and recover back to its original shape upon being triggered by different stimuli such as heat, radiation, $\mathrm{pH}$, hydration, and mechanical, magnetic, and electrical influences, etc., make polyurethane a potential candidate for several applications. Polyurethanes which are versatile materials with extraordinary characteristics, inherently have two macro-phase separated domains due to the presence of a urethane bond between soft and hard segments, alternatively. However, the urethane bond is formed due to the chemical reaction between hard segment (i.e., diisocyanate) and soft segment (i.e., polymeric diol). The capability of shape memory comes from the concept of these soft and hard segments in polyurethane. The presence of hard segment provides the mechanical strength which is responsible for it to remember the initial shape after deformation whereas the energy for dissipation is stored by soft segments providing the desired force to polyurethane in order to revive it to its initial form by the action of external stimuli [1]. The soft and hard segments in polyurethanes govern the transitions behavior triggered by radiation, sound, heat, etc., resulting in the shape memory effect. The shape memory effect in polyurethane and its composites can be one-way, two-way, triple or quadruple based on the number of transition temperatures and soft and hard contents [2-4].

The shape memory ability makes polyurethane a strong candidate for several applications such as self-tightening sutures, sensors, self-healing, implants, actuators $[5,6]$, wearable electronics, etc. It was first developed by Shunichi Hayashi and his group [7,8]. However, it has been experienced by the scientific community that pristine polyurethane does not suffice the properties required for the desired applications. Therefore, they have come up with an idea to incorporate foreign materials such as polymer, fillers, etc., in the polymer matrix which can induce the desirable property for targeted application. Incorporation of the fillers in polyurethane matrix results in enhanced 
properties such as shape memory ability, self-healing, electrical property, sensing ability, induction of bone formation, antibacterial, biocompatibility, etc. It is also observed by the scientific community that incorporation of fillers in optimized volume does not adversely affect inherent properties of polyurethanes. Incorporation of fillers such as chitosan, carbon nanotubes, lignin, hydroxyapatite, etc., can be done using blending with other polymers, bulk mixing, or in situ reactions.

Such modifications also enhance the shape memory properties along with other properties such as mechanical, electrical, and biological activities in polyurethanes. These enhanced properties of polyurethane and its composites render this material suitable for several applications. The current review collates the knowledge on various applications of shape memory polyurethane (SMP) and its composites with a special focus on human health applications such as the shielding of electromagnetic interference, medical bandage development, bone tissue engineering, self-healing, implants development, etc. For additional understanding related to history, mechanism and characterization of shape memory polymers, readers are advised to go through the other scholarly reviews [1,9-11].

\section{Shape Memory Polyurethane in Different Applications}

The inherent shape memory ability of polyurethane makes it a suitable candidate for several applications. Shape memory ability can broadly be used for the purpose of electromagnetic shielding, self-healing, pressure bandages, cardiovascular implants, bone tissue engineering, etc. which is discussed in the following sections.

\subsection{Electromagnetic Interference Shielding}

It is known that electric and magnetic signals help to regulate the behavior of living cells and processes such as control of the cell cycle, tissue regeneration, proliferation of cells, cell wound repair, etc. [12]. The global research in the biomedical field is being conducted on testing the effects of the electric and magnetic fields on the living cells which may aid in the healing process if induced with relatively low intensity. However, high intensity electric and magnetic signals may affect the cells negatively by altering biochemical reactions. The technological modernization of society has led to the evolution of vast variety of appliances and devices such as microwave ovens, computers, radio transmitter, etc., which constantly generate range of electromagnetic waves when plugged in. Various generated signals interact with other signals which may amplify and produce intense, complex, and unpredictable energetic patterns [13]. Due to this complex electromagnetic interference (EMI), health problems in living species have been raised and have also affected the performance of other electronic devices such as navigation systems in airplane, implantable cardiac pacemakers, transportation system, etc. [14]. It is essential to use EMI shielding for aerospace applications in order to protect from lighting strikes. One of the most common health hazard due to electromagnetic radiation is skin cancer. In order to avoid these electromagnetic interferences, different shielding materials with high performance have been developed by eminent scientists. Usually, EMI shielding can be achieved using shielding materials made of metals and ceramics. However, they are heavy in weight and susceptible to corrode. On the contrary, polymers are surfacing as suitable candidates to develop shielding materials due to their extraordinary properties as compared to that of metals and ceramics. The shielding materials made of polymers are easily processable, with an ability to tune their structural properties. In addition, they can render end products to be light weight, flexible, and corrosion resistant. However, it is not possible for the pristine polyurethane to be used as shielding materials due to non-conducting nature. Shielding can be done either by reflecting electromagnetic wave from the surface or absorbing the signals $[15,16]$. Most polymers (except conducting polymers) are insulators and their conductivity can be enhanced by the addition of conducting polymers into the polymer matrix. Additionally, the presence of fillers boosts thermal, mechanical, and barrier properties. It is also observed by the scientific community that improved conductivity influences the shielding effect [17]. It is also known that polyurethane and its porous composites are light weight and have the potential to absorb radiation 
due to the porosity and shape memory effect which can be an enrichment for the development of adjustable shielding material. Jin and coworkers [18] have developed a polymer based conductive or magnetic composite which has the advantage of being flexible, light weight, highly processable, and relatively economical to produce. They have used multi-walled carbon nanotubes (MWCNTs) as fillers in the SMP matrix due to their large aspect ratio and excellent electrical and mechanical properties [19]. The presence of MWCNTs contributes to the enhancement in storage modulus of SMP composite. In addition, they obtained the conductivity of $35 \mathrm{~S} / \mathrm{m}$ with $9 \%$ MWCNT loading. They concluded that electromagnetic shielding may be affected by the thickness and conductivity of the composite and they achieved $-35 \mathrm{~dB}$ of a shielding effect when tested for $13-16 \mathrm{GHz}$ with thickness of $2 \mathrm{~mm}$ containing $9 \mathrm{wt} \%$ MWCNTs. They postulated that the higher aspect ratio of the MWCNTs and the formation of percolated conductive network in the SMP matrix caused a dramatic enhancement in conductivity. In the case of SMP, direct incorporation of a high aspect ratio nanoparticles may lead to the decline in shape memory properties. It is highly required to enhance the shielding effect without compromising shape memory properties. In order to improve the shielding effectiveness and interaction of electromagnetic wave with nanoparticles, Memon et al. [20] successfully developed a new method for doping nanoparticles/MWCNTs and/or graphene oxide into a polymer matrix. They prepared the porous polyurethane membrane by way of the phase inversion method using polyethylene glycol (PEG) as pore forming agent. The developed membrane had $13 \mu \mathrm{m}$ pore size which facilitated the vacuum filtration of nanoparticles solution through the porous structure leading to the homogeneous coating of nanoparticles on the pores of membranes. They grafted magnetic $\mathrm{Fe}_{3} \mathrm{O}_{4}$ nanoparticles with graphene oxide using the solvothermal method and coated the porous membrane with same using filtration technique. It is understood that the addition of MWCNTs or any conducting fillers in SMP at less than the threshold amount—called the percolation concentration-majorly shields reflection whereas the absorption of EMI wave manifest beyond the percolation concentration. Due to the higher concentration of conducting fillers, an interconnected network forms in the bulk of SMP which leads to improved charge transport and also can be responsible for multiple scattering, ultimately reducing the intensity of the EMI wave [21]. They found that the SMP coated with MWCNTs showed shielding effectiveness of $-10 \mathrm{~dB}$ whereas SMP coated with $\mathrm{Fe}_{3} \mathrm{O}_{4}$ grafted graphene exhibited the effectiveness of $-4 \mathrm{~dB}$ at $18 \mathrm{GHz}$ for $100 \mu \mathrm{m}$ thickness. It may happen due to the formation of the percolation network. An electromagnetic (EM) wave is scattered multiple times in the bulk resulting in absorption of the EM wave. In addition, magnetic nanoparticles interact with the magnetic component of the EM wave resulting in the absorption of the wave. Overall, they come up with an idea to stack the components together and sandwich the MWCNTs composite between membrane containing $\mathrm{Fe}_{3} \mathrm{O}_{4}$ nanoparticles with graphene. They summarize that the multilayer stacked membrane showed a $-32 \mathrm{~dB}$ shielding value manifesting in $99.9 \%$ attenuation of an EM wave with $400 \mu \mathrm{m}$ thickness. The schematic of this multilayer membrane stacking (absorber-reflector-absorber) is shown in Figure 1. They also concluded that the composite had excellent heat dissipation ability which confirms the material's capability to absorb EM waves effectively without affecting shape memory properties. 


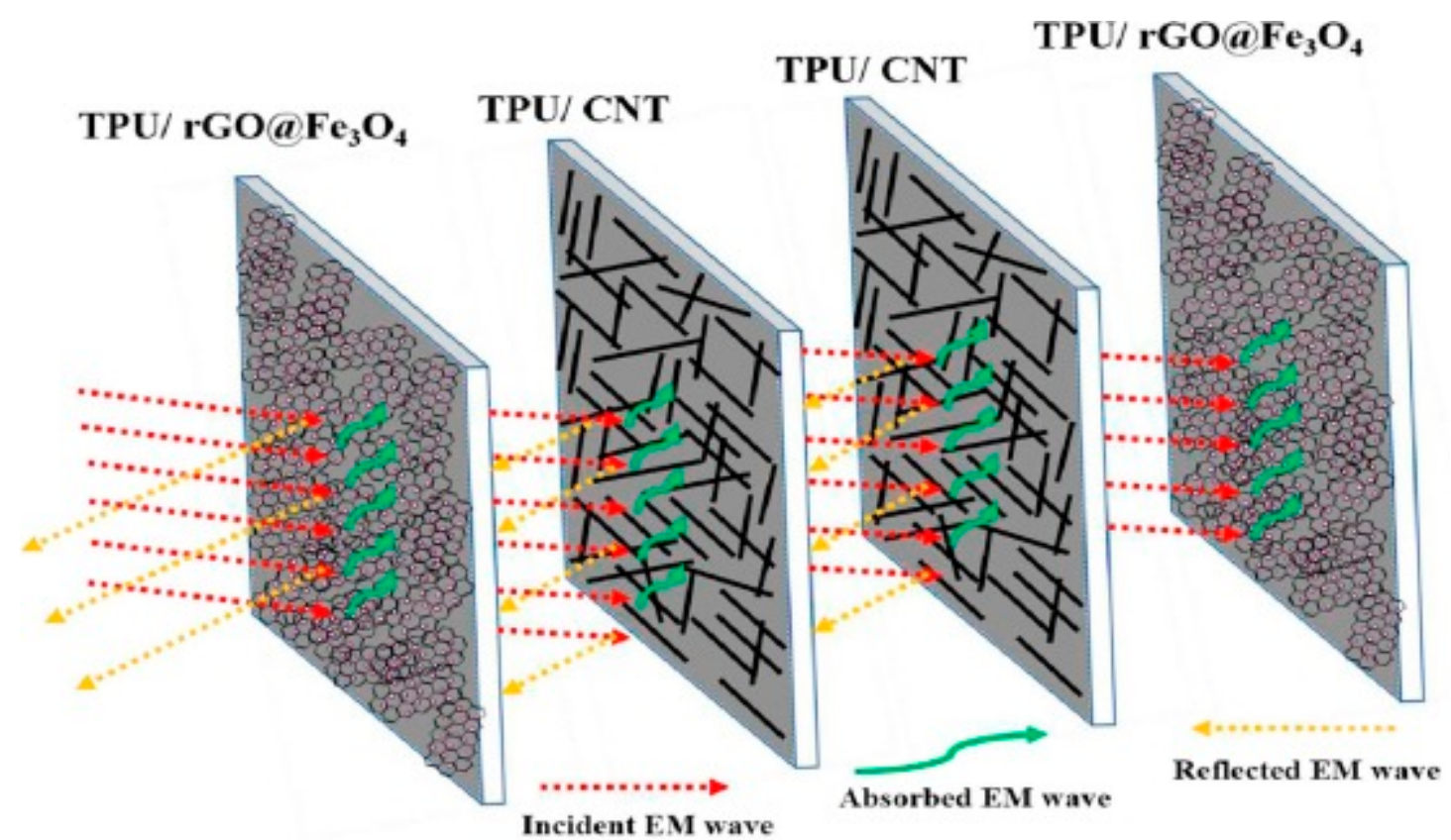

Figure 1. Illustration of the mechanism for electromagnetic wave attenuation in a multilayer sandwich structure [20].

Similarly, Yan et al. [22] proposed a novel facile method for the development of a sponge filled with graphite for electromagnetic wave shielding. They focused on preparing a high carbon loaded sponge with high porosity which can be utilized for the repeated reflection and interference of an EM wave without affecting the shape memory property. As proposed in Figure $2 b$, they prepared $a$ graphite coated melamine sponge by way of the dip coating drying method. They found that that the electrical conductivity of the sponge was enhanced to $0.01 \mathrm{~S} / \mathrm{cm}$ with an increase in the graphite content in the bulk. The shape memory activity was intact to more than $90 \%$ for $18 \%$ graphite content with the electromagnetic shielding effectiveness of $30 \mathrm{~dB}$. It indicates that the developed material achieved a shielding percentage over $99 \%$. They also proposed the mechanism for the microwave shielding shown in Figure 2a. The shielding can be achieved by the multiple internal reflection which reduces the intensity of the EM wave which is attributed as absorption of the wave.
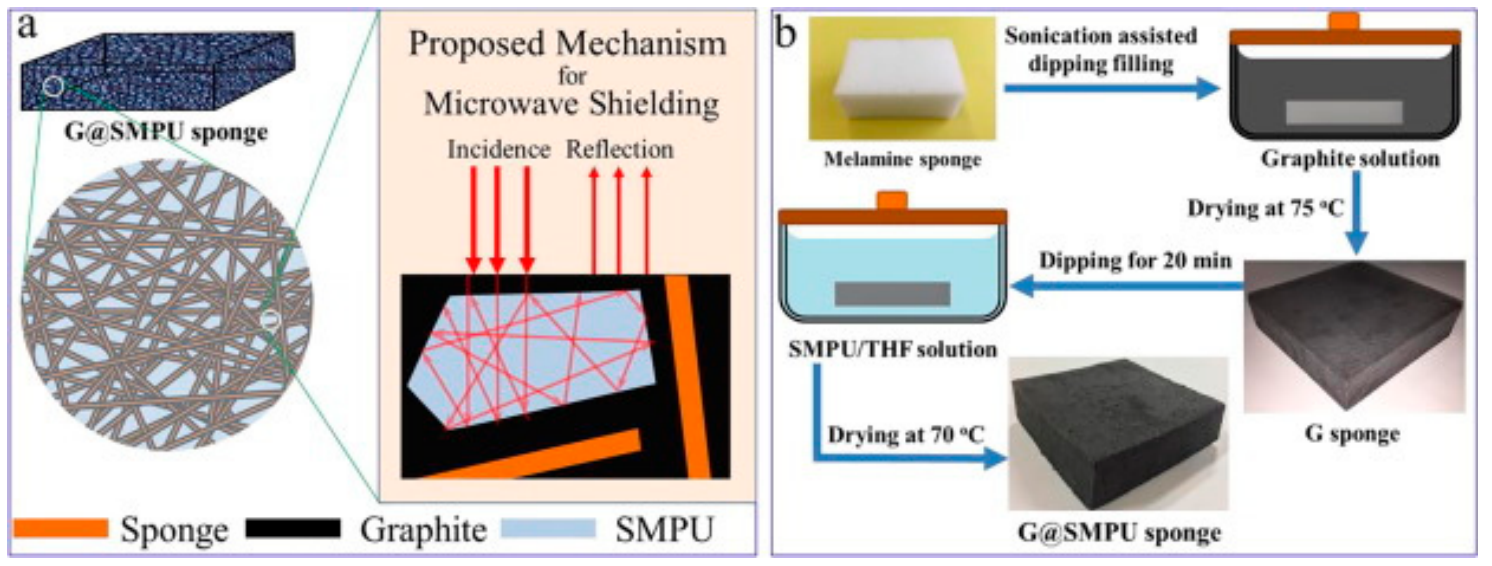

Figure 2. (a) Multi-reflection mechanism for microwave shielding, (b) fabrication method for shape memory graphite filled polyurethane sponge [22]. 


\subsection{Pressure Bandage Application}

In biomedical application, the wound and venous leg ulcer treatment is indeed a significant problem [23]. Ulcers can be developed to persons who are affected by the reduced blood flow in leg due to diabetes, rheumatoid disease, due to aging, low physical activity, etc. [24]. The increased sugar level in blood and fatty substance level on the internal wall of veins can cause progressive occlusion of the vessels $[25,26]$. The healing of an ulcer can be induced by several methods whereas the application of gradual external pressure can be extremely helpful [27]. The skin and vascular changes can be minimized or reversed by driving fluids using external compression from the interstitial spaces into the vascular and lymphatic compartments [28]. It is found from the research that the external compression should be applied in gradual fashion in an upward direction with highest pressure at the ankle [29]. The compression can be employed by the application of pressure to govern fluid retention and suppress the swelling of the lower limb. Adequate pressure can be produced using pressure bandages due to the differences in their structure and rubber/elastic yarn content. However, several factors such as shape and circumference of the limb can affect the ability of normal pressure bandages to generate sustained compression. SMPs and their composites may serve as alternatives to produce a new class of pressure bandages. SMPs have several advantages including large strain, low cost, biocompatibility, easy processability and may thus be employed in the pressure bandage application. An inherent property of the SMP is to generate strength for recovery through the release of deformation energy upon external stimuli and the same strength can be used to generate the pressure on any circular objects. Ahmad et al. [30] attempted to use the property of shape memory polymer for the pressure bandage application. They proposed two designs of bandages (Figure 3) which consisted of pre-stretched strips of temperature responsive SMPs with low transition temperature (around $50^{\circ} \mathrm{C}$ ) attached with fabric either with fixed strain of different length or fixed length of different strains. The developed bandage can be wrapped around the leg and the strips will shrink to their original shape upon application of external heat using a hair drier or a hot towel. The shrinkage of the SMP provides a coaxial force acting inwards (Figure $4 a, b$ ) with pre-defined pressure and its distribution for the venous leg treatment. The typical required pressure for the leg ulcer treatment at ankle is around $40 \mathrm{mmHg}$ which reduces to 15 $\mathrm{mmHg}$ at the upper part of leg (Figure $4 \mathrm{c}$ ).

(a)

(b)

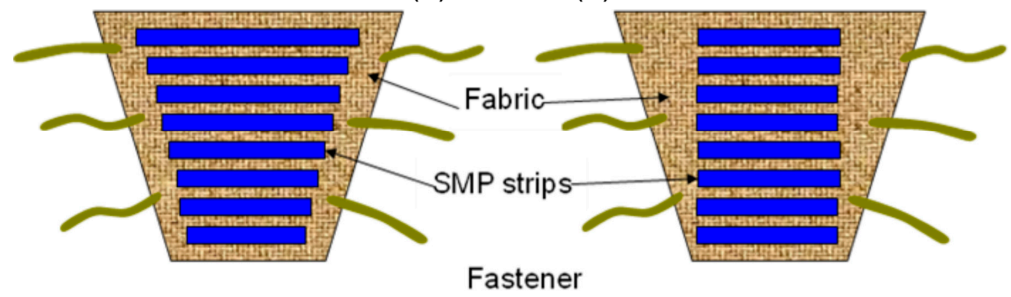

Figure 3. Proposed design of shape memory polyurethane/fabric bandages: (a) bandage consisting of strips with fixed strain of different length and (b) fixed length of different strains [30]. 
(a)

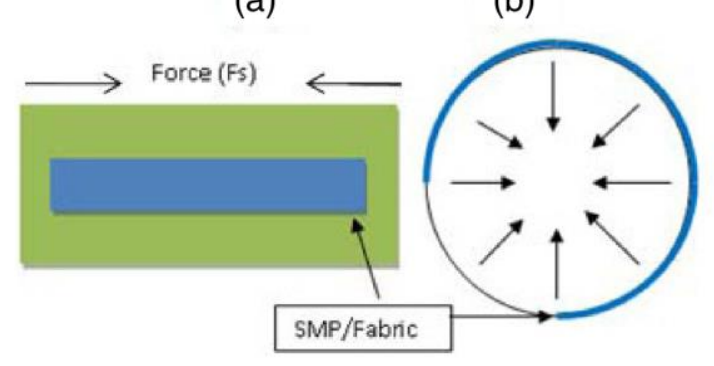

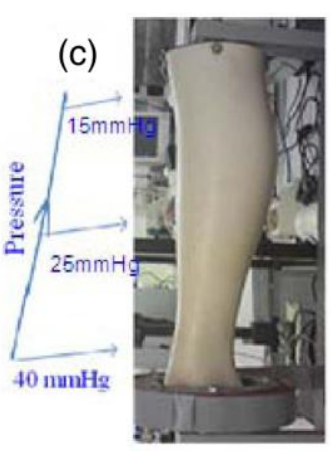

Figure 4. (a) Shape memory polyurethane strip attached on a fabric and direction of the force generated due to the activation of strip's shape memory behavior, $(\mathbf{b})$ direction of the force generated by strip attached on a circular shape, (c) model of leg with varying circumference showing pressure required for treatment of leg ulcer [30].

The aforementioned study used polycaprolactone diol as a soft segment, diisocyanate as a hard segment, and butanediol as a chain extender in the polyurethane preparation. The developed polyurethane had a maximum strain over $800 \%$ with $6.2 \mathrm{MPa}$ stress and $82 \%$ recovery ratio with a transition temperature around $45-50{ }^{\circ} \mathrm{C}$. They found from the experiments that the bandage with highly strain stored an increased amount of mechanical energy leading to the higher recovery force generating higher pressure upon heat treatment. Their results demonstrated that SMP bandages are proficient to maintain the required pressure for relatively longer duration. The immersion of bandage in water for two hours at room temperature had no measurable effect, therefore, sweating and body fluid may not affect its performance significantly. The inventors of this pressure bandage have notified that the generated pressure may drop during use and can be readjusted by any non-skilled person at home using hot towel or hair drier which considerably simplifies the treatment. They also concluded that SMP bandages can be used multiple times by using higher activation temperature without dropping their shape memory ability.

Woven and non-woven textiles made out of shape memory polyurethanes or in combination with other polymer filaments [31-33] can also be used for pressure bandages (also referred as smart stockings) and produce a massage effect. Stress control mechanism in shape memory fabric materials for providing dynamic compression can be an improvement for chronic patients. In this concern, Narayana et al. [34] attempted to integrate shape memory polymeric filaments with nylon filament in order to produce optimum pressure via structural optimizations. They found that fabric structure and physical parameters such as float length, loop length, stitch density, etc., affect the interfacial pressure for the development of desired compression. They also found that the heating and cooling cycle can help in the development of dynamic stress on legs and maintain the desired pressure. The structure with short loop length $(2.5 \mathrm{~mm})$ showed extra pressure $(25 \mathrm{mmHg})$ and controlled the massage effect by stocking which significantly enhanced the blood flow velocity in the vein.

For further research and suitable application in biomedical area, same SMPs can be used along with nanofibers [35] having drug release capability for smart bandages.

\subsection{Bone Tissue Engineering}

More than 4.5 million reconstructive surgical procedures are reported to be executed yearly worldwide in response to the bone injuries [36]. A constant increase in diseases such as osteoporosis, tumors, and osteonecrosis has also been witnessed due to disordered lifestyle responsible for annihilation of bone tissues. In addition, traumatic injuries or ineffective healing after traumatic injuries leads to the destruction of bone tissues. Generally, our body heals the bone fractures naturally using different bone cells. The process of bone healing begins with bleeding and as the blood flows down to the bone fracture site, it forms a clot resulting in swelling in the broken area. Further, the dead cells and germs are cleaned up by a force of white blood cells and the blood clot starts to reduce. This triggers 
the osteoclasts cells to remove the broken dead bone rubbles followed by the formation of fibrocartilage tissues with the help of chondroblasts cells which hold the broken bone ends together. Simultaneously, osteoblasts and fibroblasts start building the bone tissues and producing collagen fibers, respectively, in combination and produce tissue called as soft callus. The soft callus begins to harden with time which is called as bony callus and the excessive bone tissue reabsorbed by osteoclasts leads to a healed and healthy bone. The time taken for the healing process may differ on the basis of different conditions such as general health condition, presence of infection, age of the person, blood supply condition, and the type of breakage. The small defects in the bones are healed naturally by the growth, renewal, and repair mechanism as explained previously. However, in case of bone defects bigger than the critical size, the healing process turns out to be crucial and it becomes necessary to develop new bone regeneration techniques using tissue engineering methods. Tissue engineering is mainly based on three fundamental things which constitute a template for the tissue formation which is a porous three-dimensional scaffold made of osteoinductive biomaterials, cells for tissue generation, and growth factors. The porous scaffolds should have the capability to support cell adhesion, proliferation, and differentiation promoted by growth factors. The structural and mechanical integrity of the scaffold are the vital parameters to facilitate and regulate the daily cellular processes and bone healing. In addition, the degradation rate of biomaterials should be consistent with the growth rate of new tissues. Therefore, designing the scaffold for the purpose of regenerating target tissue may be regarded as the most important part in tissue engineering. Bone tissues can be repaired using scaffolds made of different ceramics, metallic and polymeric materials [37] such as polylactic acid (PLA) [38], polycaprolactone (PCL), polyglycolic acid (PGA), polypropylene fumarate (PPF), polyurethanes, polyhydroxyalkanoates (PHA), silk fibroin, chitosan, alginate, cellulose, etc. [39]. Different aspect of biopolymers as a bone substitute is discussed elsewhere [40].

In the process of designing scaffolds and their implantation in human body, it is always beneficial to have precisely matched dimensions with the contour of bone defect. Therefore, polymers or their composites with shape memory properties can contribute significantly and scientists and researchers have developed different materials for the same application. Due to advantage of shape memory programming, polyurethane and its composites can maintain a temporary structure of interest and recover as per the need after incorporation in bone via minimal invasive bone repair [41]. Correia and coworkers [42] developed a chitosan based scaffold which possess shape memory ability triggered by hydration. The same group [43] added bioactive glass nanoparticles in chitosan by sol-gel method in order to enhance bioactivity and biomineralization ability of chitosan scaffold without affecting shape memory with a $89.9 \%$ recovery ratio. A bone like apatite layer was formed due to presence of bioactive glass when the scaffold was subjected to simulated body fluid (SBF), which suggested the suitability of the material for bone tissue engineering. The developed dehydrated composite scaffold with the temporary shape was placed in a defect of pig femur bone model which was occupied the defect contour after rehydration (Figure 5). The hydration driven shape memory permits a relatively good fixation trough a press-fitting effect.

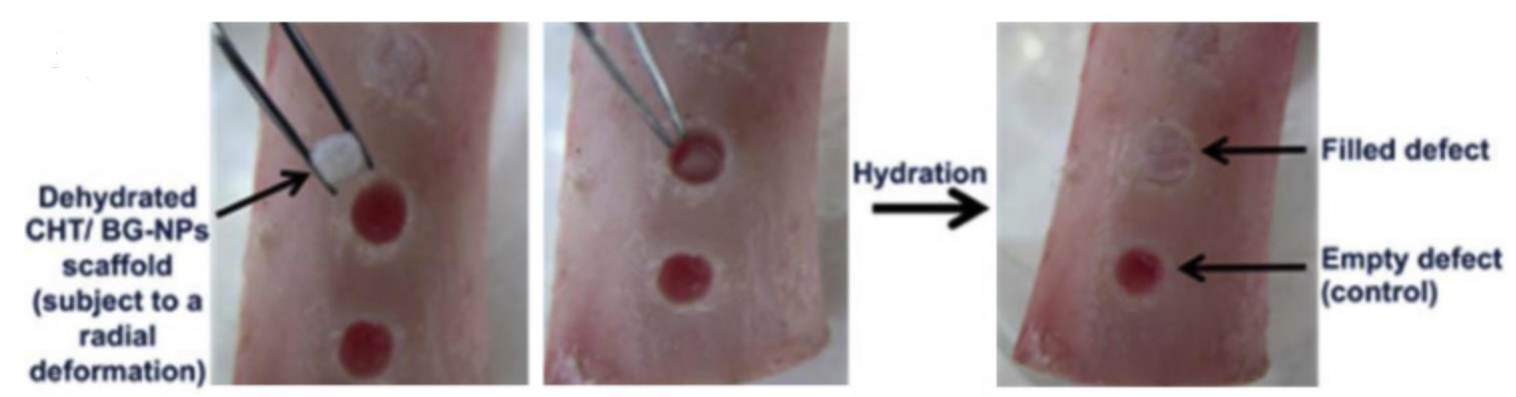

Figure 5. Demonstration of recovery in a defect produced in a pig femur bone using chitosan bioglass nanoparticle (CHT/BG-NPs) composite scaffold [43]. 
Similarly, Leite et al. [44] prepared chitosan based shape memory spheres driven by hydration by incorporating bioactive glass nanoparticles using sol-get method and using genipin used as a cross-linker. An apatite layer was formed on the surface of the spheres immersed in SBF which confirmed the compatibility to bone tissue formation. They demonstrated the shape memory ability of chitosan composite sphere for bone regeneration using a self-fitting technique. Chitosan spheres with an optimized percentage of bioactive glass $(10 \%)$ and genipin $(10 \%)$ can be added to the bone defects with predefined shape followed by self-fitting due to rehydration (Figure 6) with a shape recovery ratio of more than $88 \%$. The spheres were demonstrated to be used for drug delivery purposes. They postulated that, after hydration, the presence of an interconnecting porous network between spheres may work as pores allowing transport of oxygen, cellular invasion, and nutrient access. Along with the biopolymers, biobased and biodegradable polymer-based polyurethanes are being used for the purpose of bone tissue engineering.
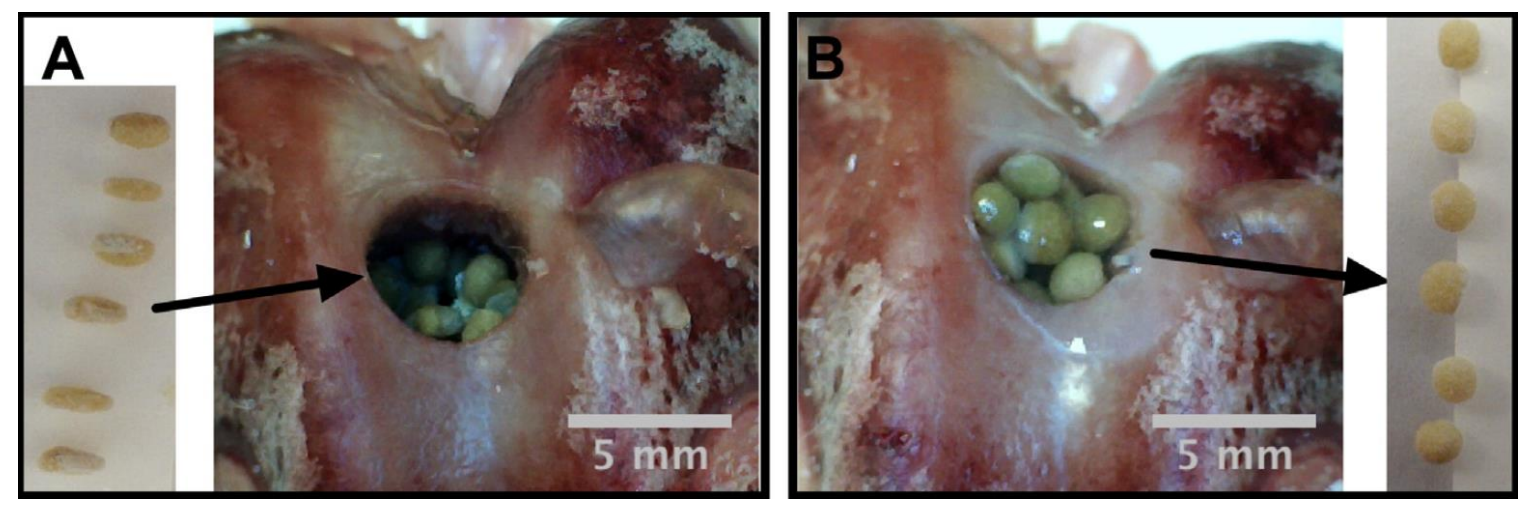

Figure 6. Digital picture of shape recovery of chitosan spheres containing $10 \%$ bioactive glass nanoparticles and 10\% genipin in a defect created in a rabbit femur bone: (A) before hydration, (B) after hydration [44].

In the recent past, superparamagnetic iron oxide (SPIO) nanoparticles have been widely employed for several applications such as tissue repair, detoxification of biological fluids, hyperthermia, drug delivery, etc. [45]. Wang and coworkers [46] have utilized SPIO's ability to promote the osteogenic induction of human bone derived mesenchymal stem cells (hBMSCs) [47] for the development of bone scaffold based on waterborne SMPs which contain SPIO nanoparticles along with polyethylene oxide or gelatin as thickener. Three-dimensional scaffold was printed using low-temperature fuse deposition manufacturing platform and used for bone tissue regeneration. The matrix of polyurethane was made of using PCL, PLA, and diisocyanate. The developed scaffold demonstrated an effective shape memory property when fixed in predefined defect and exposed to warm water. The results indicated that the release of SPIO promoted the osteogenesis of hBMSCs in scaffolds (Figure 7) and secretion and deposition of collagen and calcium. 
A

hMSCs seeding

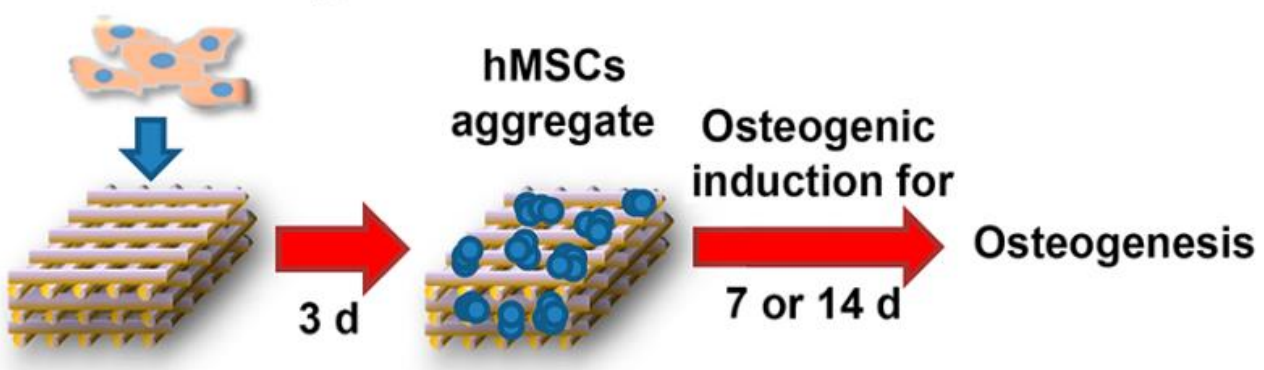

B

C
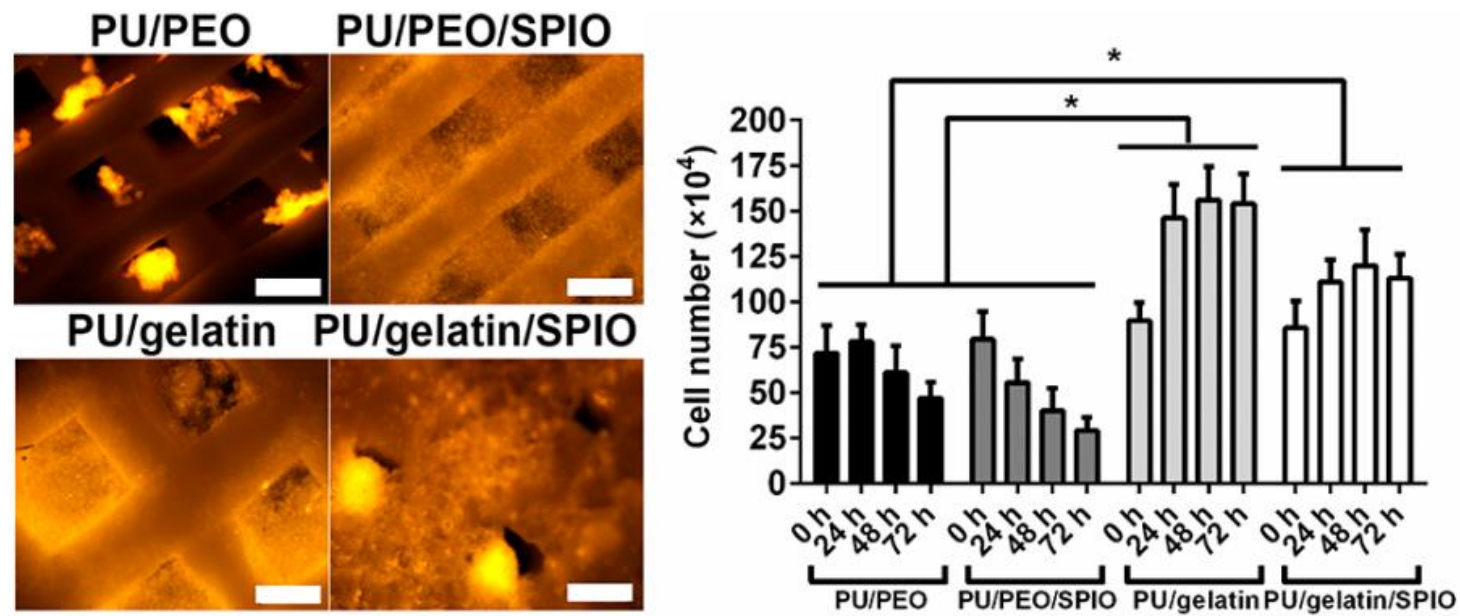

Figure 7. (A) Schematic of three dimensional (3D) shape memory scaffold seeding process with human mesenchymal stem cells (hMSCs), (B) fluorescent images of hMSCs in 3D scaffolds after 24 hour culture, (C) number of cells (hMSCs) cultured during 72 hour culture time [46].

Similarly, Xie and coworkers [48] utilized hydroxyapatite (HA) nanoparticles in the fabrication of SMP foam using gas foaming technique for the treatment of load bearing bone defects. Chemical similarity to natural bone matrix ( $\sim 69 \mathrm{wt} \% \mathrm{HA}$ ) [49] make HA exhibit strong affinity toward host hard tissues. In addition, HA has advantages such as osteoconductivity, osteoinductivity, biocompatibility which make HA useful for bone repair and bone augmentation [50,51]. Xie et al. found that SMP foam with HA revealed excellent biocompatibility for bone tissue regeneration and promoted bone ingrowth and neovascularization. They also found that the time of 12 weeks was sufficient for the bone repairing (Figure 8). It can be understood from the above mentioned literature that the reported materials had not undergone clinical trials which hinders the use of these materials for the purpose of human bone tissue engineering. It is the need of the hour to conduct long term research using animal models in order to find the clinical feasibility and use these materials for practical bone tissue engineering applications. 


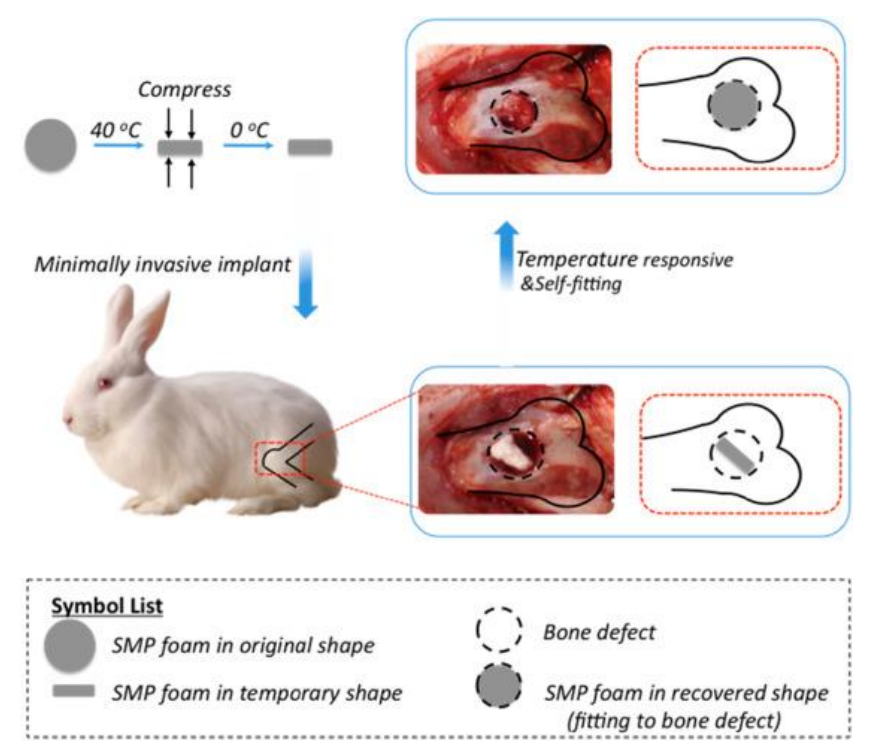

Figure 8. Schematic representation of self-fitting shape memory polymer foam as scaffold for bone regeneration and growth after surgery [48].

\subsection{Self-Healing}

Designing polymeric materials mimicking the characteristics of living organisms which constitute the prevention from outer attack, self-degradation, etc., has attracted the focus of the scientific community. Polymeric materials with self-repairing capability can enhance safety, reliability, and the quality of humans. Inspired from nature, scientific groups have tried to develop materials which have a self-healing or self-repairing property. A detailed discussion on the principle of healing and crack-closing in polymers and their composites can be found elsewhere [52]. It is known that most polymeric materials are based on covalent bonds and are naturally limited not to regain initial strength after damage due to random reason [53] or they may have a non-covalent bond or act as host guest polymer [54] or an external stimuli driven dynamic covalent bond may characterize the polymer with self-healing ability [55-58]. Several research works are listed in Table 1 along with self-healing, shape memory, and mechanical properties. The self-healing capability along with shape memory properties can be an additional feature for any polymer for several applications. However, as the shape memory property is a physical phenomenon and does not involve any chemical bond brakeage and formation, it may not be fully possible to recover $100 \%$ of damage. Fan et al. [59] have utilized microcapsules in bulk technique to produce SMP comprising self-healing ability called cooperative self-healing. They produced the microcapsules of a healing agent (Alodine 5200, mainly containing hexafluorotitanic acid $\left(\mathrm{H}_{2} \mathrm{TiF}_{6}\right)$ and hexafluorozirconic acid $\left.\left(\mathrm{H}_{2} \mathrm{ZrF}_{6}\right)\right)$ by coating a layer of polyurethane (toluene diisocyanate and 1,4-butanediol based polyurethane) over healing agent as core. The SMP coating on the aluminum alloy (substrate) with self-healing ability was developed by adding polyurethane coated Alodine capsules into PEG based SMP using a bar coating at an elevated temperature. The capsules present in the bulk of the polyurethane break due to generation of defects and react with the substrate and prevent the substrate to be corroded. Cooperative self-healing is completed upon heating by triggering shape recovery $(79.6 \%)$. The entire cooperative process of self-healing with shape memory property is illustrated in Figure 9. 
Table 1. Summary of shape memory polyurethanes along with self-healing, shape memory, and mechanical properties.

\begin{tabular}{|c|c|c|c|c|c|c|c|c|c|c|c|c|c|}
\hline \multirow{2}{*}{ Material } & \multicolumn{6}{|c|}{ Mechanical Properties } & \multicolumn{2}{|c|}{$\begin{array}{c}\text { Transition } \\
\text { Temperatures }\end{array}$} & \multicolumn{2}{|c|}{ Self-Healing Properties } & \multicolumn{2}{|c|}{ Shape Memory } & \multirow{2}{*}{ Ref } \\
\hline & $\begin{array}{l}\text { Deformation } \\
\text { Parameters }\end{array}$ & UTS & E (\%) & Toughness & $\begin{array}{l}\text { Impact } \\
\text { Resistance }\end{array}$ & $\begin{array}{l}\text { Thermal } \\
\text { Stability }\end{array}$ & $\operatorname{Tg}$ & $\mathrm{Tm}$ & Parameters & $\begin{array}{l}\text { Self-Healing } \\
\text { Efficiency }\end{array}$ & $\begin{array}{l}\text { Recovery } \\
\text { Ratio }\end{array}$ & $\begin{array}{l}\text { Fixing } \\
\text { Ratio }\end{array}$ & \\
\hline PUVs & $\begin{array}{l}\text { stretch under } 0.1 \\
\text { MPa load }\end{array}$ & 7.3 MPa & 833.4 & - & - & $300^{\circ} \mathrm{C}$ & - & $40{ }^{\circ} \mathrm{C}$ & $\begin{array}{l}80^{\circ} \mathrm{C} \text {, heating rate } \\
30^{\circ} \mathrm{C} \mathrm{min}^{-1}\end{array}$ & - & $100 \%$ & $96 \%$ & [60] \\
\hline PCL diol & $\begin{array}{l}\text { scratched using } \\
\text { razor blade }\end{array}$ & - & - & - & - & - & - & $\begin{array}{c}50 \sim 60 \\
{ }^{\circ} \mathrm{C}\end{array}$ & $80^{\circ} \mathrm{C}, 1 \mathrm{~h}$ (oven) & $97 \%$ & $94.6 \%$ & $95 \%$ & [61] \\
\hline SHZPU & $\begin{array}{l}\text { scratch by glass } \\
\text { slide }\end{array}$ & - & - & - & - & $200^{\circ} \mathrm{C}$ & $23.5^{\circ} \mathrm{C}$ & - & heating at $80^{\circ} \mathrm{C}$ & $97 \%$ & $88.2 \%$ & $\sim 100 \%$ & [62] \\
\hline SMPU & $\begin{array}{l}\text { scratched with a } \\
\text { razor blade }\end{array}$ & - & - & - & - & - & - & $70^{\circ} \mathrm{C}$ & $\begin{array}{l}\text { heating at } 80^{\circ} \mathrm{C} \text { for } \\
24 \mathrm{~h}\end{array}$ & - & - & - & [63] \\
\hline IPNs & heated at $70^{\circ} \mathrm{C}$ & $12.6 \mathrm{MPa}$ & $1608 \%$ & $\begin{array}{c}92.34 \mathrm{MJ} \\
\mathrm{m}^{-3}\end{array}$ & $\begin{array}{c}26.8 \mathrm{~kJ} \\
\mathrm{~m}^{-1}\end{array}$ & $245^{\circ} \mathrm{C}$ & $\begin{array}{l}44 \text { to } 44.1 \\
{ }^{\circ} \mathrm{C}\end{array}$ & $29.2^{\circ} \mathrm{C}$ & $\begin{array}{c}62 \mathrm{~s} \text { at } 450 \mathrm{~W} \\
\text { microwave } 6-8 \mathrm{~min} \\
\text { under sunlight }\end{array}$ & - & $100 \%$ & $98 \%$ & [64] \\
\hline $\begin{array}{l}\text { PU/SBS/ } \\
\text { MWCNTs }\end{array}$ & $\begin{array}{l}\text { stretched to a } \\
\text { strain of } 500 \% \text { at } \\
60^{\circ} \mathrm{C} \text { for } 5 \mathrm{~min}\end{array}$ & - & - & - & - & - & - & $44.1^{\circ} \mathrm{C}$ & $100^{\circ} \mathrm{C}$ for $24 \mathrm{~h}$ & $81.4 \%$ & - & - & [65] \\
\hline $\begin{array}{l}\text { SMPU- } \\
\text { OOBAm }\end{array}$ & $\begin{array}{l}\text { elongated at } 100 \\
{ }^{\circ} \mathrm{C}\end{array}$ & - & - & - & - & - & - & $77^{\circ} \mathrm{C}$ & $\begin{array}{c}40 \mathrm{~min} \text { at } 80^{\circ} \mathrm{C} \text { and } \\
100^{\circ} \mathrm{C}\end{array}$ & $\begin{array}{l}90 \% \text { at } 100^{\circ} \mathrm{C} \text { for } \\
\text { approximately } \\
20 \mathrm{~min}\end{array}$ & $90 \%$ & $98 \%$ & [66] \\
\hline ZSMPU & $\begin{array}{c}100 \% \text { strain heated } \\
\text { to } 60^{\circ} \mathrm{C}\end{array}$ & - & 200 & - & - & - & $\begin{array}{l}26.6 \text { to } \\
48.7^{\circ} \mathrm{C}\end{array}$ & - & $\begin{array}{c}\text { moisture-rich } \\
\text { conditions }\left(30^{\circ} \mathrm{C}\right. \\
\text { and } 80 \% \mathrm{RH} \text { and } \\
\text { drying at } 50{ }^{\circ} \mathrm{C} \text { for } 2 \\
\mathrm{~h} \\
\end{array}$ & - & $97.50 \%$ & $98.05 \%$ & [67] \\
\hline c-PCL-2OH & $\begin{array}{l}\text { surgical blade and } \\
\text { put in an oven }\end{array}$ & $16 \mathrm{MPa}$ & 135 & - & - & $\begin{array}{l}48 \mathrm{~h} \text { at } 60 \\
{ }^{\circ} \mathrm{C}\end{array}$ & - & $55^{\circ} \mathrm{C}$ & $\begin{array}{c}130^{\circ} \mathrm{C} \text { for } 4 \mathrm{~h}, \\
\text { followed by being } \\
\text { kept at } 60^{\circ} \mathrm{C} \text { for } 48 \mathrm{~h}\end{array}$ & - & $60 \%$ & $\sim 99.5 \%$ & [68] \\
\hline PEUR-SS $x$-Ns & $\begin{array}{l}\text { scraped by a fresh } \\
\text { razor blade }\end{array}$ & $15.5 \mathrm{MPa}$ & 1864 & - & - & - & $\begin{array}{c}25 \text { to } 75 \\
{ }^{\circ} \mathrm{C}\end{array}$ & $23.2^{\circ} \mathrm{C}$ & $\begin{array}{l}\text { heated to } 55^{\circ} \mathrm{C} \\
\text { about } 12 \mathrm{~h}\end{array}$ & $\begin{array}{c}94 \% \text { at } 55^{\circ} \mathrm{C} \text { for } \\
12 \mathrm{~h}\end{array}$ & $97.4 \%$ & $99.9 \%$ & [69] \\
\hline PIB-FGOs & surgical blade & $9.1 \mathrm{MPa}$ & 125.8 & - & - & - & $\begin{array}{c}53.3-62.2 \\
{ }^{\circ} \mathrm{C}\end{array}$ & $\begin{array}{l}17.9-19.8 \\
{ }^{\circ} \mathrm{C}\end{array}$ & $\begin{array}{l}\text { exposed to near } \\
\text { infrared light lamp } \\
\text { wavelength of } 808 \\
\mathrm{~nm} \text { at a distance of } \\
\sim 20 \mathrm{~cm} \text { for } 10 \mathrm{~min}\end{array}$ & $40-60 \%$ & $\begin{array}{l}87.22- \\
95.06 \%\end{array}$ & $\begin{array}{l}83.75- \\
91.78 \%\end{array}$ & [70] \\
\hline
\end{tabular}


Table 1. Cont.

\begin{tabular}{|c|c|c|c|c|c|c|c|c|c|c|c|c|c|}
\hline \multirow{2}{*}{ Material } & \multicolumn{6}{|c|}{ Mechanical Properties } & \multicolumn{2}{|c|}{$\begin{array}{c}\text { Transition } \\
\text { Temperatures }\end{array}$} & \multicolumn{2}{|c|}{ Self-Healing Properties } & \multicolumn{2}{|c|}{ Shape Memory } & \multirow{2}{*}{ Ref } \\
\hline & $\begin{array}{l}\text { Deformation } \\
\text { Parameters }\end{array}$ & UTS & E (\%) & Toughness & $\begin{array}{l}\text { Impact } \\
\text { Resistance }\end{array}$ & $\begin{array}{l}\text { Thermal } \\
\text { Stability }\end{array}$ & $\operatorname{Tg}$ & $\mathrm{Tm}$ & Parameters & $\begin{array}{l}\text { Self-Healing } \\
\text { Efficiency }\end{array}$ & $\begin{array}{c}\text { Recovery } \\
\text { Ratio }\end{array}$ & $\begin{array}{l}\text { Fixing } \\
\text { Ratio }\end{array}$ & \\
\hline SMPU-TDI & $\begin{array}{l}\text { stretched into a } \\
\text { length as long as } \\
\text { possible at a } \\
\text { sufficiently high } \\
\text { temperature }(70 \\
\left.{ }^{\circ} \mathrm{C}\right) \text { for } 1 \text { min with } \\
\text { a hair dryer }\end{array}$ & - & - & - & - & - & - & - & $\begin{array}{l}\text { heated at } 75^{\circ} \mathrm{C} \\
\text { for } 2 \mathrm{~h}\end{array}$ & - & $79.6 \%$ & 一 & [59] \\
\hline $\begin{array}{l}\text { TPU/PCL/ } \\
\text { MWCNTs }\end{array}$ & $\begin{array}{l}\text { under the external } \\
\text { forces }\end{array}$ & - & - & - & - & - & $\sim 60^{\circ} \mathrm{C}$ & $\sim 60^{\circ} \mathrm{C}$ & - & $96 \%$ & $63.9 \%$ & $96.8 \%$ & [71] \\
\hline
\end{tabular}

UTS: Ultimate tensile strength, PUVs: Polyurethane-vitrimers, PCL diol: Poly(e-caprolactone) diol, SHZPU: Self-healing zwitterionic polyurethanes, SMPU: Shape-memory polyurethane,

IPNs: Interpenetrating polymer networks, PU: Polyurethane, SBS: Styrene-butadiene-styrene, SMPU-OOBAm: Shape-memory polyurethane-4-octyldecyloxybenzoic acid, ZMSPU:

Zwitterionic multi-shape-memory polyurethanes, c-PCL-2OH: Cyclic poly( $\varepsilon$-caprolactone), l-PCL-2OH: Linear poly( $\varepsilon$-caprolactone), PIB-FGO: Polyisobutylene-functionalized graphene

oxide, TID: Toluene diisocyanate, TPU: Thermosetting polyurethane, MWCNTs: Multi-walled carbon nanotubes, E (\%): Elongation at break. 


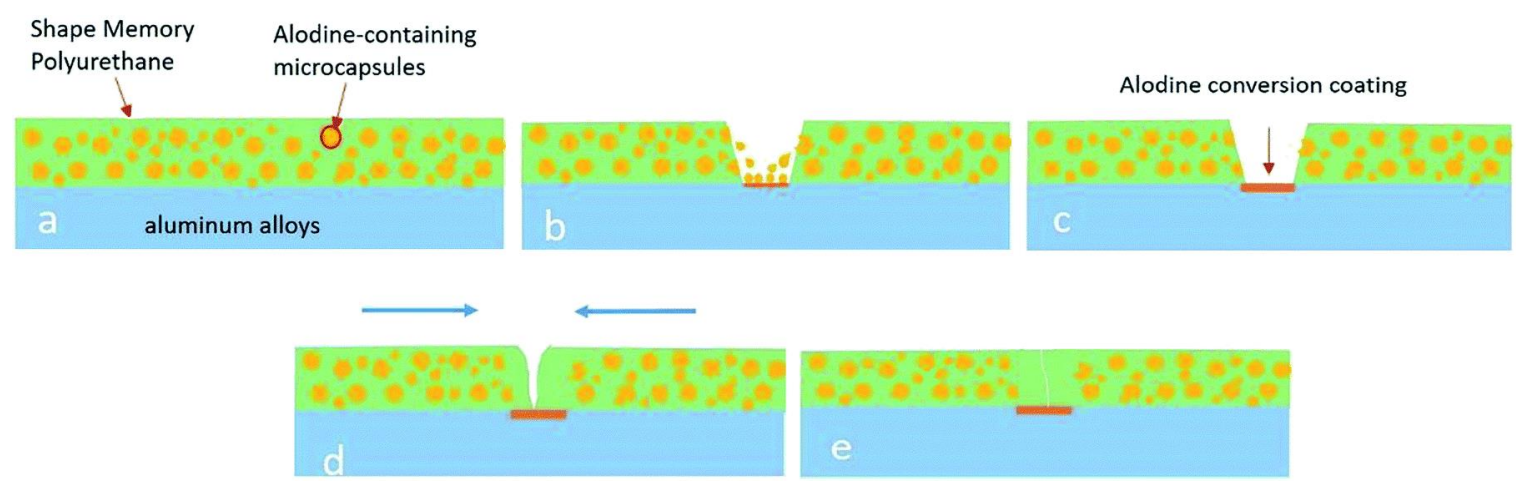

Figure 9. Schematic representation of cooperative self-healing: (a) Alodine microcapsules loaded polyurethane coating on aluminum alloy, (b) release of Alodine from the microcapsules caused by defect, (c) formation of Alodine conversion coating on aluminum alloy, (d) shape memory effect of polyurethanes stimulated by external heat, (e) completion of healing process of scratch [59].

Yan et al. [60] have developed a renewable castor oil based polyurethane vitrimers [72,73]. Vitrimers are crosslinked thermosets which can easily be processed or recycled due to interchange transesterification process upon heating. In this study, the developed polyurethane vitrimers contain intrinsic carbamate bond which undergo transcarbamoylation/transesterification reaction in the presence of dibutyltin dilaurate as a catalyst and govern the thermally induced dual shape memory and self-welding ability. They found an increase in the stress of the welded samples with welding time whereas higher temperature promoted the welding ability (Figure 10). 

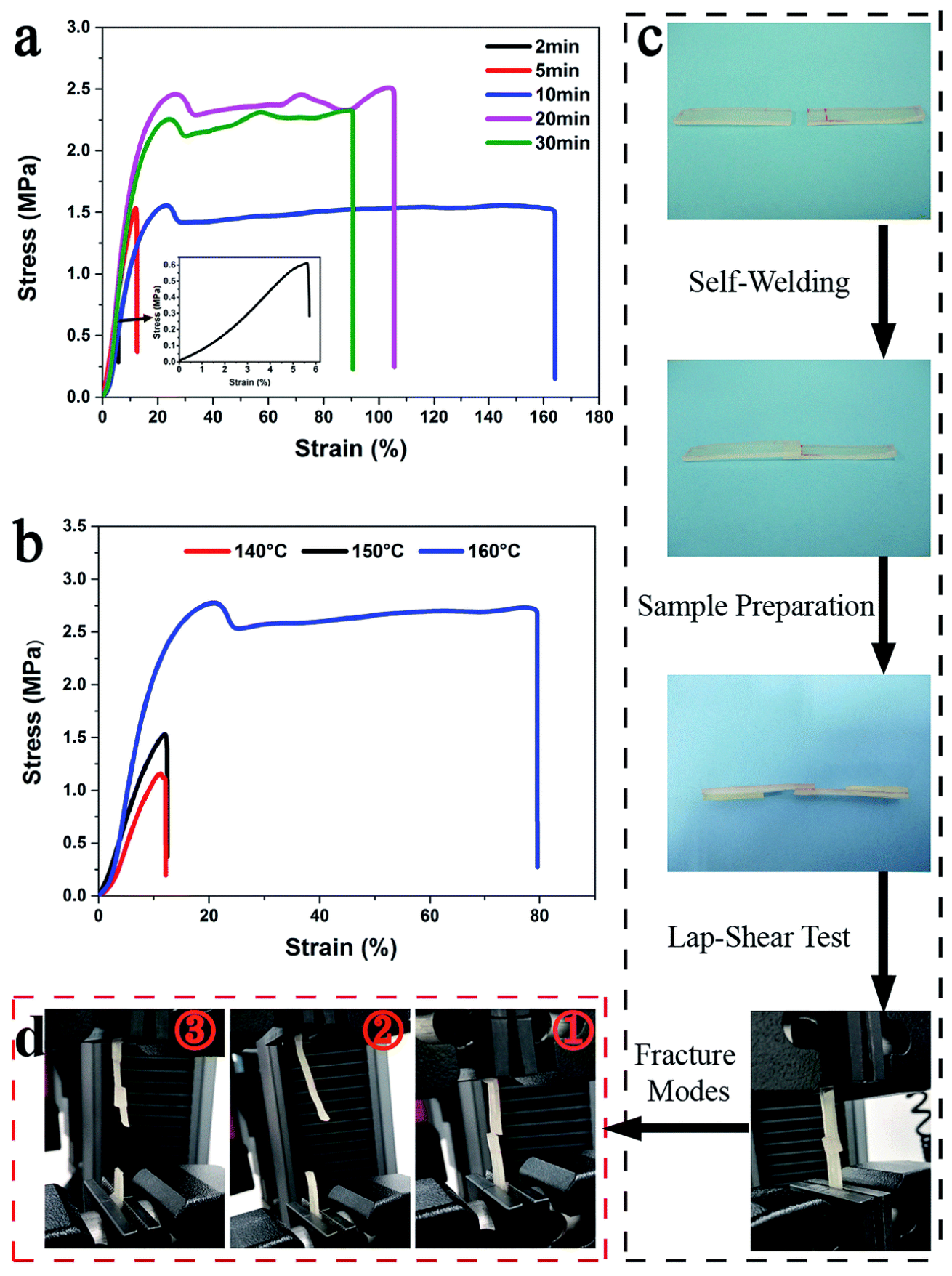

Figure 10. Demonstration for self-welding ability of welded polyurethane vitrimers with $3 \mathrm{wt} \%$ catalyst dibutyltin dilaurate (PUV-3) sample: Stress-strain curve (a) at different time at $150{ }^{\circ} \mathrm{C}$ and (b) at different temperatures for 5 min welding, (c) lap-shear test, (d) modes of fracture of different samples [60].

In another work reported by $\mathrm{Xu}$ et al. [71], the demonstration of the self-healing and shape memory ability of thermoplastic polyurethane and polycaprolactone blended with MWCNTs has been made using melt-blending technique. They disclosed that the addition of MWCNTs could allow the polyurethane blend to respond to near infrared (NIR) radiation and achieve healing repeatedly. Physical healing (nearly 96\%) of sliced pieces of the developed blend was found to reach to its original flexibility after three minutes of NIR exposure $(808 \mathrm{~nm}, 0.5 \mathrm{~W})$ and the damaged surface was fully recovered (Figure 11). They also postulated that the use of NIR radiation could control the self-healing and shape memory capability remotely. 

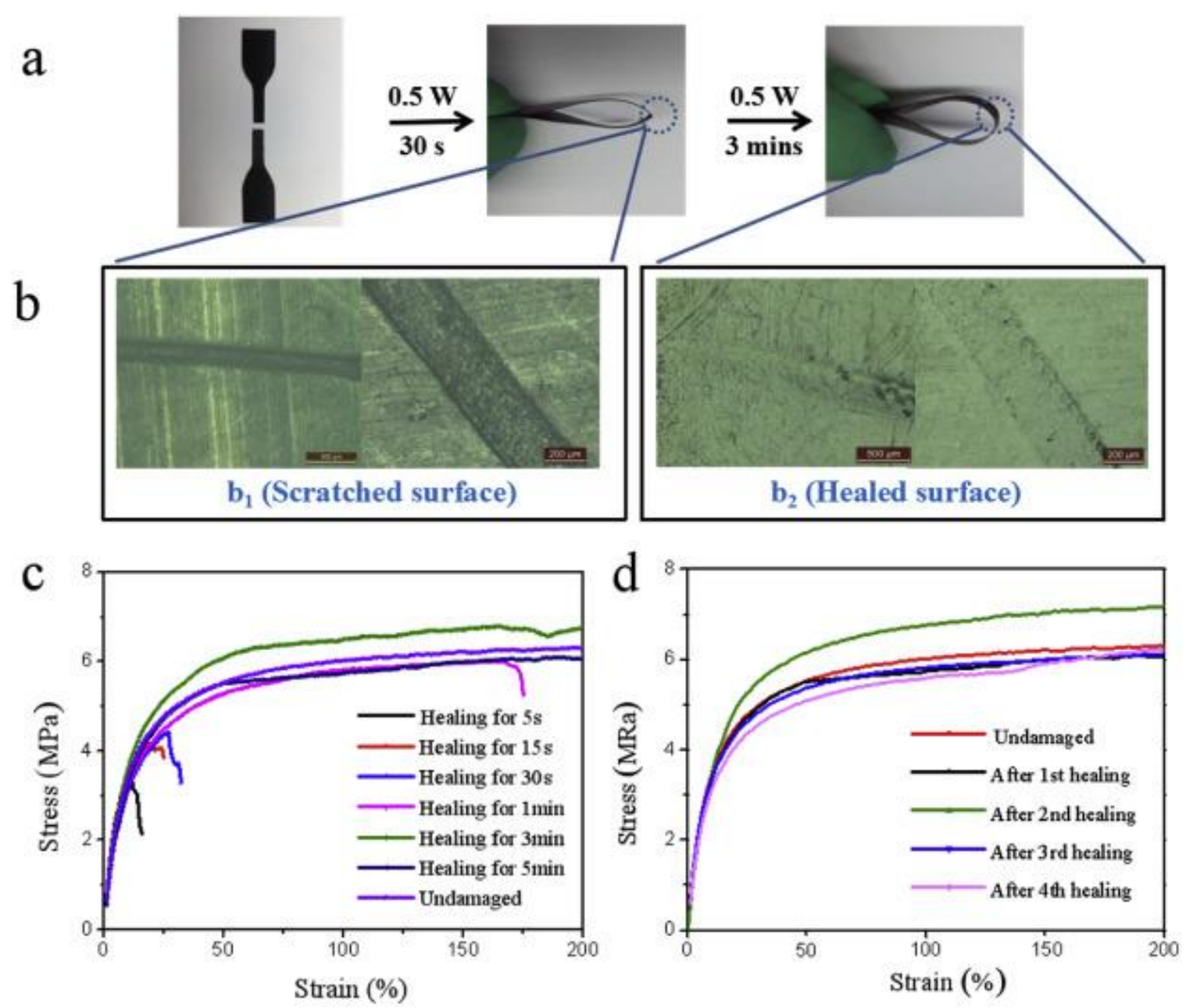

Figure 11. (a) Illustration of the healing process of polyurethane composite with $50 \%$ thermoplastic polyurethane, $50 \%$ polycaprolactone and 3\% MWCNT (U1C1-3) using near infrared (NIR) irradiation $(808 \mathrm{~nm}, 0.5 \mathrm{~W}, 15 \mathrm{~cm})$, (b) optical images of scratched and healed surfaces, stress-strain curves for U1C1-3 samples (c) with different irradiation times and (d) with healing cycles [71].

In another similar work, Du et al. [70] reported the self-healing and shape memory properties of polytetramethylene ether glycol (PTMEG) based polyurethane containing diselenide bonds induced by NIR radiation. In order to enhance the photo-thermal activity resulted from NIR radiation, they covalently incorporated the functionalized graphene oxide into polyurethane. They found that the presence of diselenide bonds greatly enhanced the self-healing capability $(\sim 90 \%)$ of the prepared composites. They concluded that the synergistic photo-thermal response and dynamic exchangeable diselenide bond contributed towards the curing of damaged sites resulting in complete healing. Similarly, Deng and colleague [69] have used the same PTMEG based polyurethane embedded with dynamic covalent bonds using disulfide bond in its backbone chain which are responsible for its conditional self-healing ability. Increasing the content of disulfide bond (12\%) showed efficient self-healing efficiency $(94 \%)$. After the damage, the prepared material was healed due to the disulfide exchange in the matrix at elevated temperature $\left(55^{\circ} \mathrm{C}\right)$ for $30 \mathrm{~min}$. In a work reported by Fan et al. [65], utilization of the dynamic reversible covalent bonding for repeated intrinsic self-healing of wider cracks in PCL based polyurethane has been presented. They prepared the composite of polyurethane, styrene-butadiene-styrene block copolymer (SBS), and MWCNTs. They modified the crosslinked elastomeric SBS block copolymer sphere via an addition of alkoxyamine into the backbone and used as internal stress generator (Figure 12). Incorporation of alkoxyamine moieties, which works as intermolecular links, gives an additional feature of synchronous bond fission/radical 
recombination based on dynamically reversible C-ON bond to SBS. Heating to its homolysis temperature, the temperature at which the chemical bond dissociation of molecules occur and the involved electrons distribute between the formed fragments, triggers synchronous covalent bond fission and radical recombination among alkoxyamine moieties is triggered which help repeatedly self-healing without affecting the mechanical and shape memory properties [74]. They also incorporated MWCNTs to improve the electric conductivity of insulating polyurethane which helped to stimulate shape memory by Joule heating.

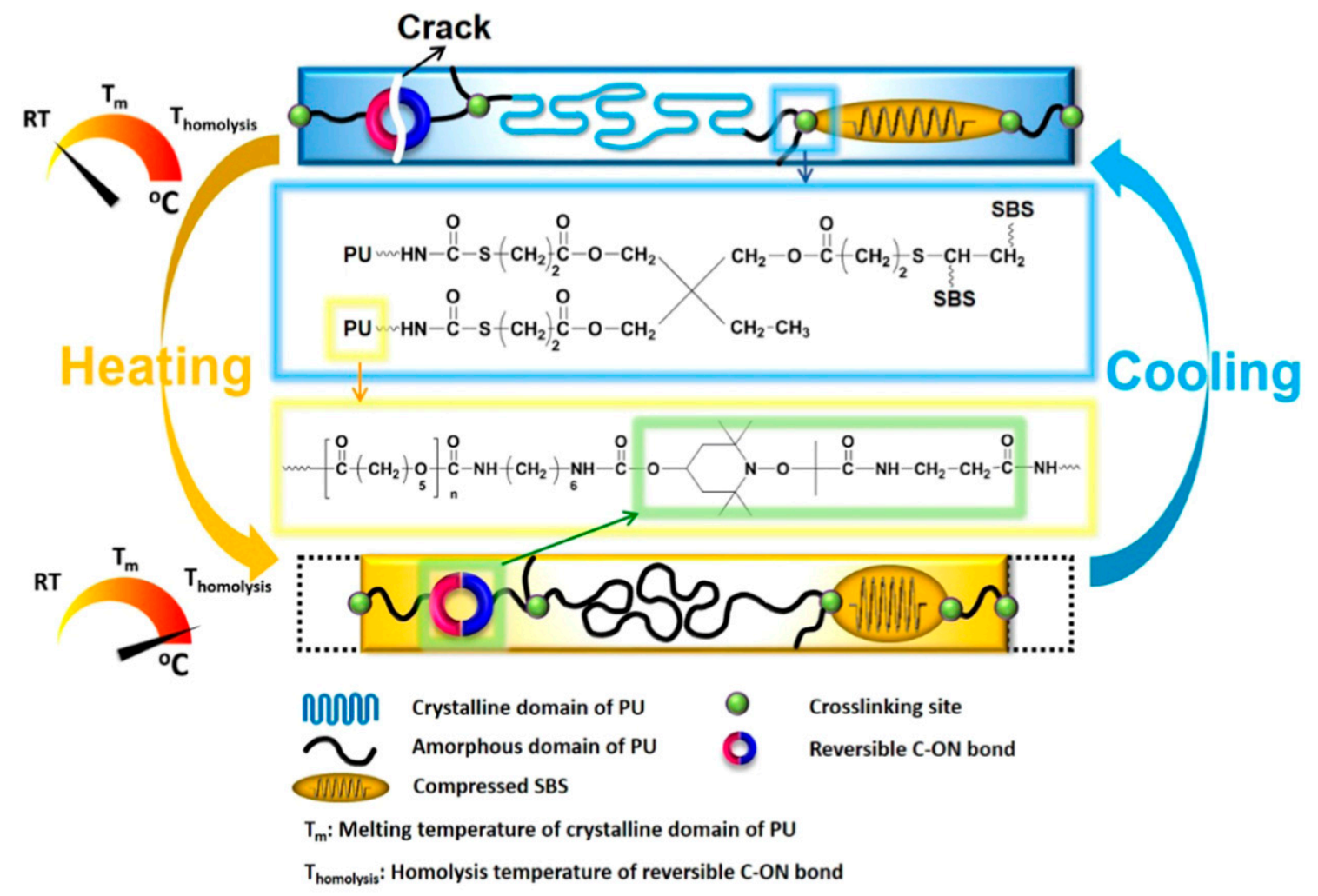

Figure 12. Conceptual representation of built-in synergetic reversible self-closing and intrinsic self-healing capability of polymer through dynamic reversible covalent bonding along with shape memory property [65].

In the exploration of materials with self-healing ability, Chen and coworkers [68] developed polyurethane based on cyclic polycaprolactone and incorporated dynamic covalent bond into the polymer system by the addition of furan and maleimide moiety (Diels-Alder adducts). They found cyclic topology of polycaprolactone affected the shape memory and self-healing properties of the developed crosslinked polyurethane. They established using Fourier-transform infrared spectroscopy technique that furan and maleimide were formed into the polymeric system upon thermal heating at $130{ }^{\circ} \mathrm{C}$ for $5 \mathrm{~min}$ due to the retro Diels-Alder reaction which disappeared after cooling to $60^{\circ} \mathrm{C}$ for 48 hours. Overall, the developed material showed 70\% self-healing ability as per the mechanical pull test. Self-healing can also be triggered using moisture or water hydration and dehydration at relatively lower temperatures. Focusing on this advantage, Chen et al. [67] developed a novel zwitterionic multi-shape-memory polyurethanes (ZSMPUs) using N-methyldiethanolamine as soft segment, hexamethylene diisocyanate (HDI) as hard segment and 1,3-propanesultone (PS). They used PS to graft zwitterionic side chains onto the backbone of polyurethane via a ring opening mechanism which forms zwitterionic units. Normally, zwitterions are the dipolar ions with zero net electric charge having two or more functional groups containing at least one positive and one negative charges [75-77]. Introduction of the zwitterions may help to enhance biocompatibility, hydrophilicity, and multi shape memory ability of cross-linked polyurethanes. Exposure to moisture rich conditions $\left(30^{\circ} \mathrm{C}\right.$ and $80 \%$ 
$\mathrm{RH}$ ) for few minutes makes the wounded polyurethane sample soft and sticky and slight pressure leads to healing. Moreover, the developed interface of healing zone was also diminished upon heating the sample at $50{ }^{\circ} \mathrm{C}$ for 2 hours. It was also concluded that the healing process does not affect the shape memory ability of prepared polyurethane (Figure 13). They ascribed this healing process to the supramolecular zwitterionic interaction which takes part in holding the sample together before rebuilding of the regular entangled network across the wounded surfaces.

A
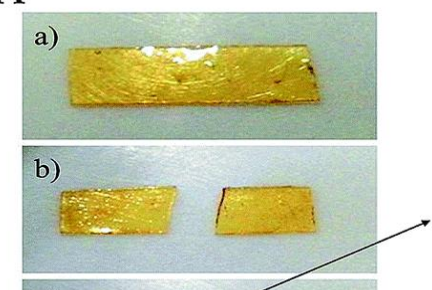

c)

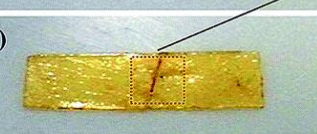

d)
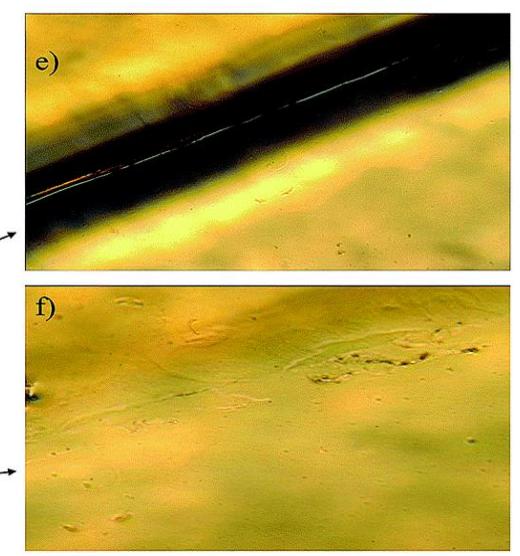

$\mathrm{B}$

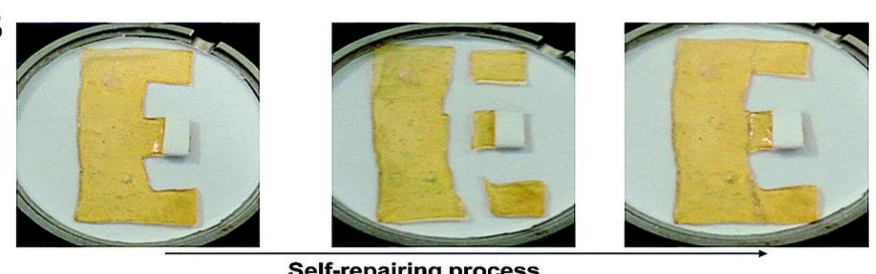

Self-repairing process

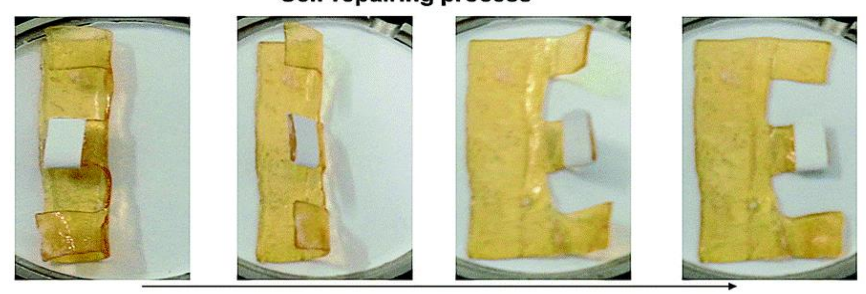

Shape recovery process of self-healed polymers

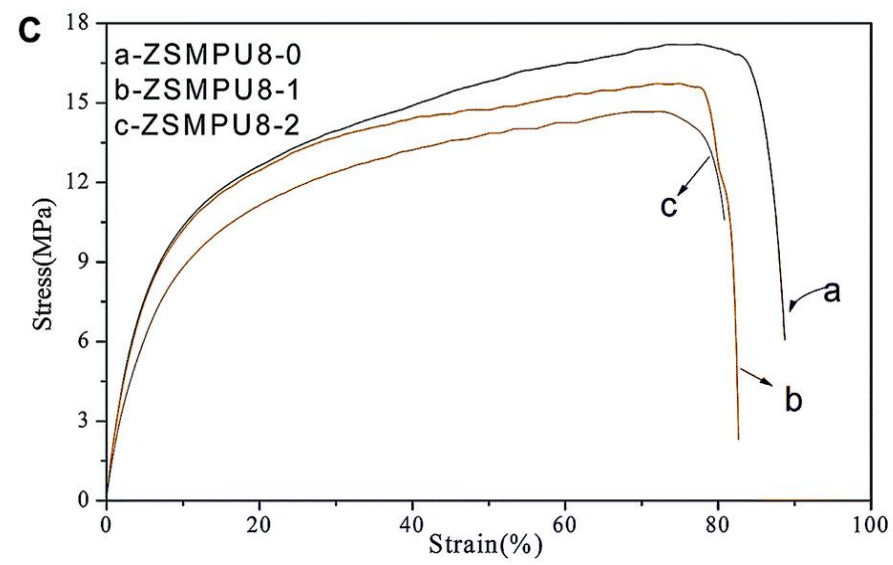

Figure 13. (A) Self-healing behavior of ZSMPU8 along with (B) its shape memory ability and (C) the stress-strain curve with healing cycle [67]. 
Similarly, Wen and coworkers [62] reported the preparation of zwitterion polyurethane using $\mathrm{N}, \mathrm{N}$-bis (2-hydroxylethyl) isonicotinamide as soft segment and HDI as hard segment along with the incorporation of zwitterions into the backbone. Integration of zwitterions was done by way of a ring opening of PS. The developed material contained pyridine type sulfobetains responsible for the strong electrostatic interactions which also acted as physical crosslinkers. It is known that the shape memory ability was based on the phase transition and, in this case, the aggregation of zwitterions influenced the phase transition behavior of polyurethane. They also concluded that the increase in zwitterions leads to enhanced self-healing efficiency in most humid environments without any additive and external energy. It was also concluded that the hydration of the material increases ionic mobility whereas electrostatic forces improve upon dehydration. During hydration, the zwitterions may migrate to a wounded surface and hold the surfaces together via increased crosslinking upon dehydration (Figure 14).
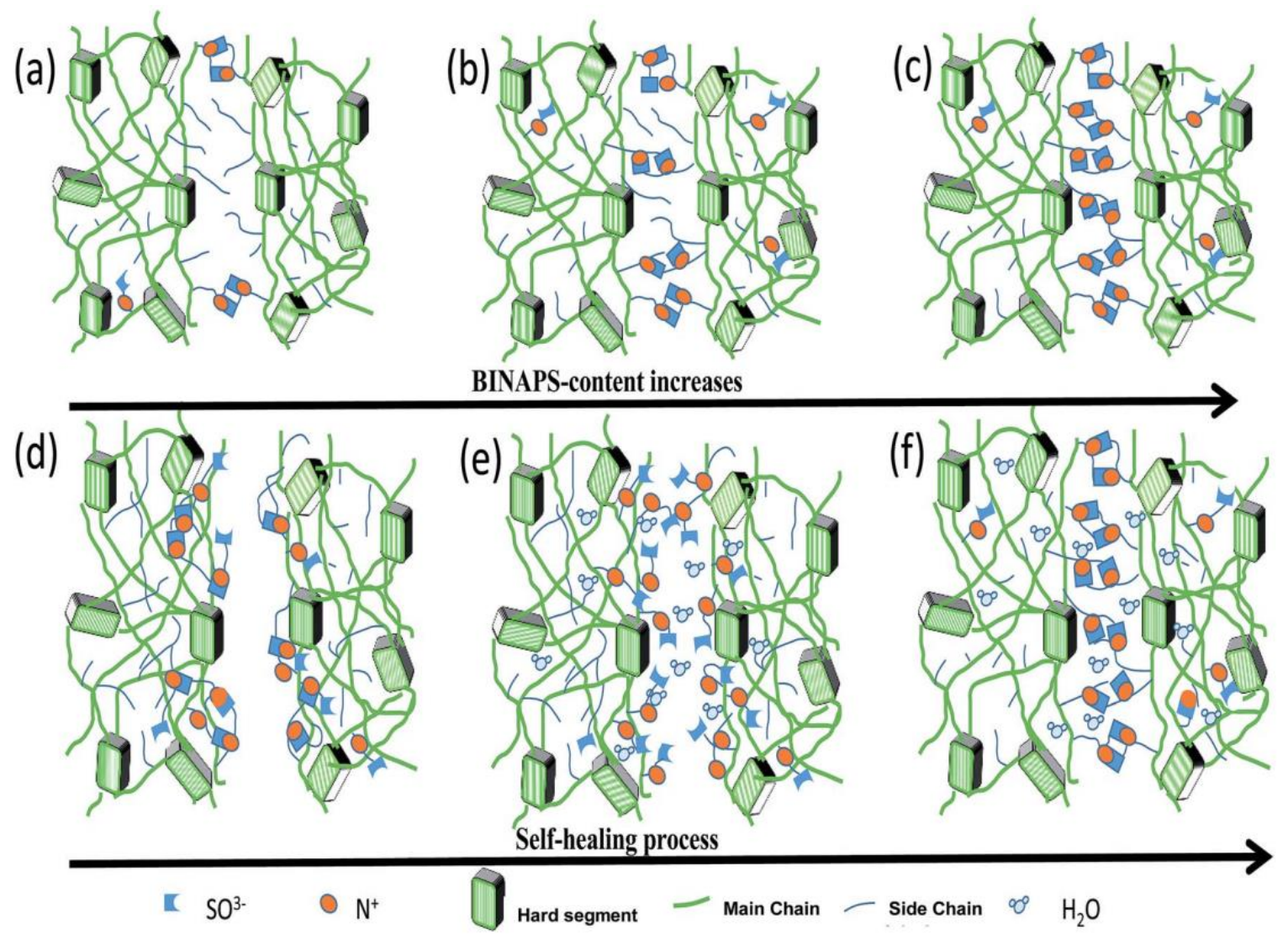

Figure 14. Illustration for the use of zwitterionic moieties in the self-healing of polyurethane [62].

Development of polyurethanes with self-healing ability can also be done by incorporation of liquid crystalline material. In this scenario, Ban and coworkers [66] integrated 4-octocyloxy benzoic acid (OOBA) into PEG based polyurethane using solution phase mixture. They found an enhanced self-healing ability of polyurethane along with a shape memory property and proposed a new mechanism of heat induced bleeding. Bleeding of liquid crystal (OOBA) at the wounded surface, due to the enhanced fluidity of molecules, upon heating at $130^{\circ} \mathrm{C}$ and forming crystals via crystallization process results in self-healing or heat induced healing of damage. They stated that the developed composite can be used as flexible printed circuits, self-healing concrete, and self-protecting textiles.

\subsection{Cardiovascular Implants}

Cardiovascular implants such as stents, grafts, etc., are applicable to repair or replace diseased arteries in living body. As the occurrence of chronic and cardiovascular disease is increasing in society, the commercial market for these implants is escalating. Millions of patients have benefited by the 
use of cardiovascular implants recently [78]. Their basic function is to work as artificial conduit or replacement for non-functional veins. As an artificial conduit, cardiovascular implants should have the ability to mimic the mechanical and biological behavior of an artery which helps to sustain a prolonged healing process $[79,80]$. A suitable cardiovascular implant can be derived from basic understanding of structural and functional properties of artery as they are involved in both blood and soft tissue interaction [81]. In the development of implants, design optimization is perceived as one of the most critical step. Therefore, it is always a booming area for the scientific community.

Recent technological advancement opened the door for the development of new and innovative implants which can improve the diagnosis process of the patients [82]. Use of a shape memory metal alloy such as an NiTi alloy for the development of vascular devices like stents, occlusion coils has attracted the scientific community's attention $[83,84]$. Devices made of metal and its alloys have several advantages. However, they are too stiff and their design prevents them from the navigation in arteries. In the context of implants development, shape memory polymers can easily be processed/molded into the required size and shape using different techniques $[85,86]$ along with externally stimulated actuation. Several researchers have developed SMP for implants using different materials such as palm oil [87], PCL-PLA with $\mathrm{Fe}_{3} \mathrm{O}_{4}$ [88], perfluoropolyether [89], etc. Therefore, there is a requirement for devices which have access and delivery into the tortuous arteries made of polymers having flexibility and a high shape recovery ratio.

In this perspective, Baer and coworkers [90] have proposed a stent prototype developed using biocompatible SMP [91]. The stent was prepared using the dip coating technique on a stainless steel pin followed by drying in vacuum. In order to create the mesh pattern on the prepared stent, the laser etching method was applied to $50 \%$ of the solid stent (Figure 15). They found that the developed laser etched stent showed full shape recovery with an expansion ratio of 2.7 and $1 \%$ axial shortening after crimping. In addition, the device did not begin to self-expand during navigation into the artery and it can show the controlled actuation by an external heat source.

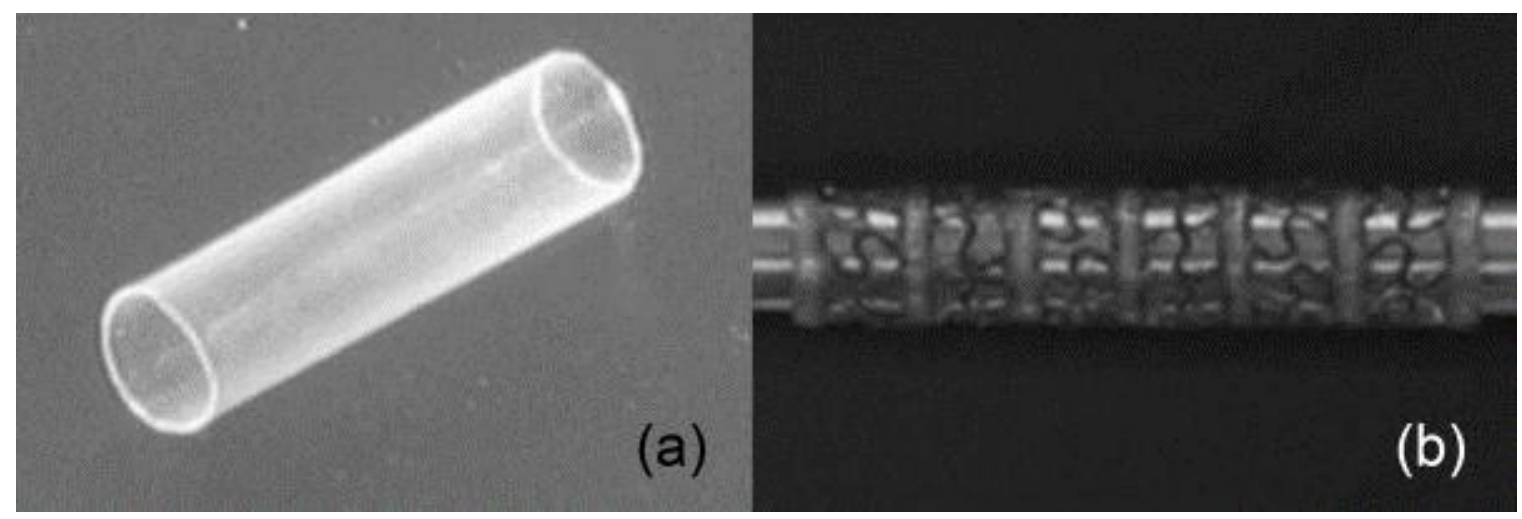

Figure 15. (a) Representative $4 \mathrm{~mm}$ tubular stent, (b) laser etched high flexible stent and details of the pattern [90].

In another work, Ajili and coworkers [92] developed a material by blending polyurethane and PCL by melt mixing in Brabender internal mixer in different ratios (70/30). They found that the material's shape memory can be simply actuated with the help of body temperature which is a desired property for the implants such as stent. The screw stent made of blended material can be deformed at higher temperature $\left(40^{\circ} \mathrm{C}\right)$ and be fixed at lower temperature $\left(10^{\circ} \mathrm{C}\right)$ for 2 hours followed by the recovery of the initial shape upon exposure to water at $37^{\circ} \mathrm{C}$. The applicability of the same screw stent was tested in a segment of human femoral vein at human body temperature (Figure 16). The stent (6 mm diameter) was placed into a $4 \mathrm{~mm}$ diameter vein after compressive shape fixing using delivery instrument. After submerging vein with stent into water at $37^{\circ} \mathrm{C}$, the stent was found to recover to its original shape and expand the wall of vein. They also concluded that the prepared material was biocompatible in nature as determined from the adhesion and proliferation of bone marrow mesenchymal stem cells. 
a

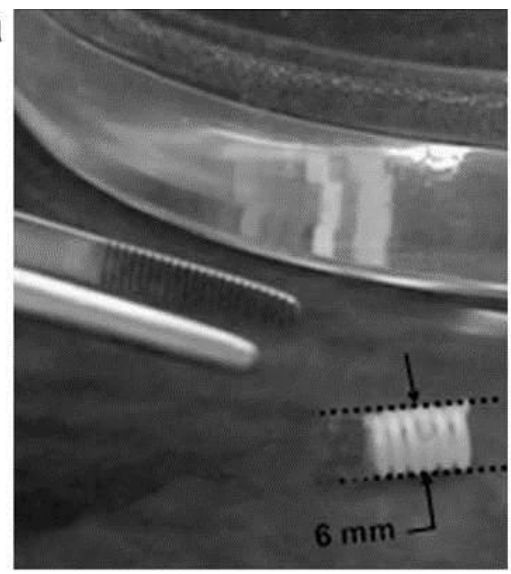

b

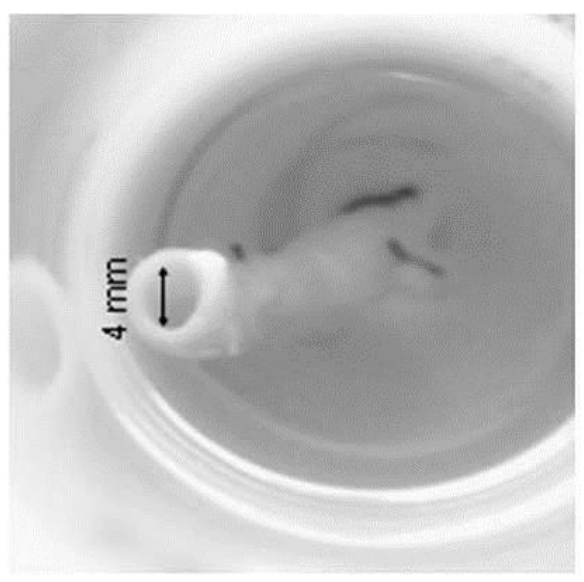

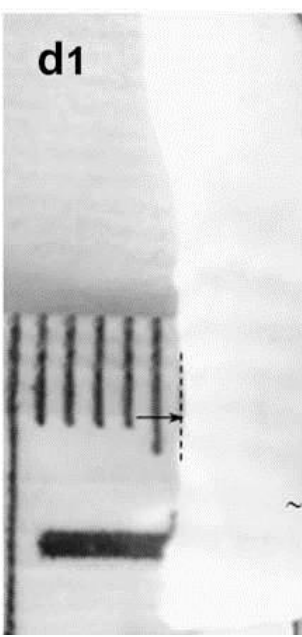

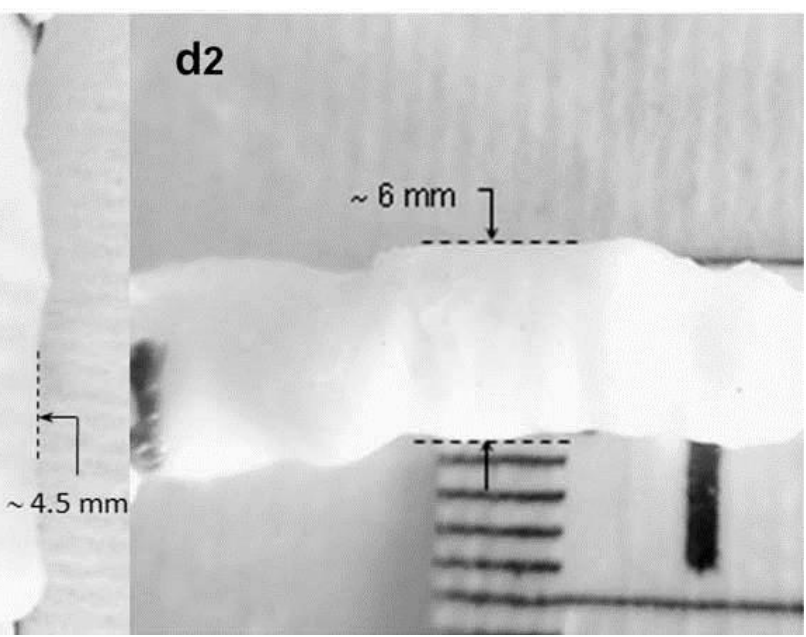

Figure 16. (a) Representative performance of screw (PU/PCL), (b) in femoral vein segment from leg of patient, (c) stent in stretched shape over a delivery instrument, (d1-d2) shape recovery step of the stent delivered in femoral vein in water at $37^{\circ} \mathrm{C}$ [92].

The development of implants and its design using three-dimensional (3D) printing technique can be ground-breaking. A key advantage of 3D printing technique is that one can customize the design of object based on patient requirement. Kim and Lee [93] presented a novel design of bifurcated stent through the use of kirigami structures fabricated using 3D printing of SMP. The design of bifurcated stent on the basis of kirigami structure supports to produce transformable ' $Y$ ' shape from compactly folded initial shape and helps in smooth travel inside branched vein [94-96]. The shape memory was demonstrated by fixing its shape to the compact structure via shortening at above glass transition followed by cooling. The memorized structure was regained upon heating again above the glass transition temperature. They also demonstrated the bifurcated stent (Figure 17) and found increased usefulness in case of irregular forms of blood vessels. 
(a) 3D model of blood vessel

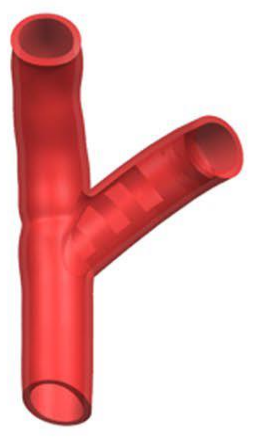

(b) Stent design from blood vessel model

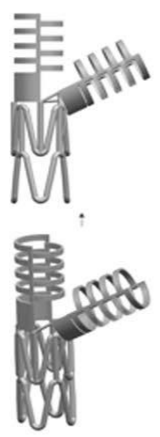

(d) Deformation and recovery process of main and side branch

Deformation

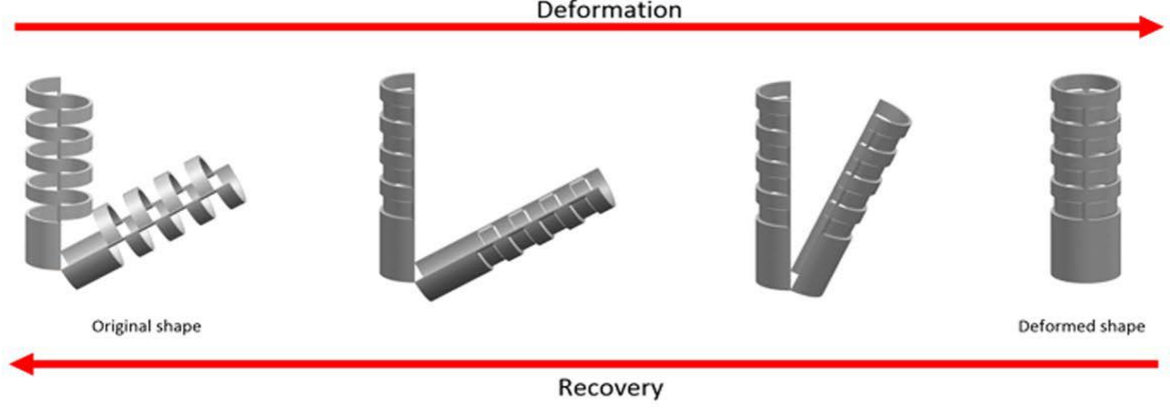

(e) Bifurcated stent deployment process

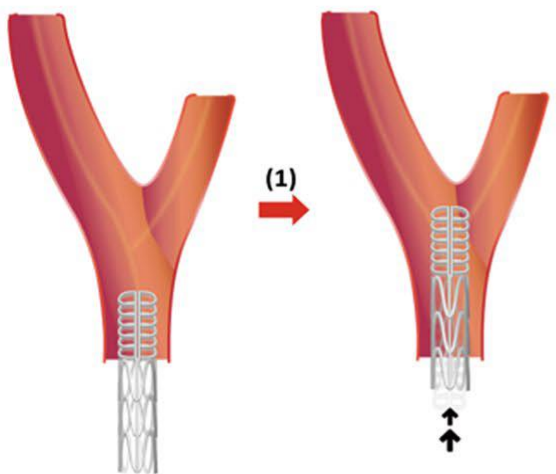

(f) Bifurcated stent deployment experiment
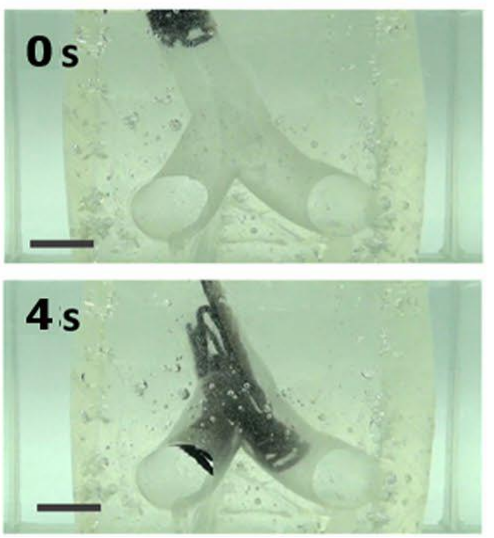
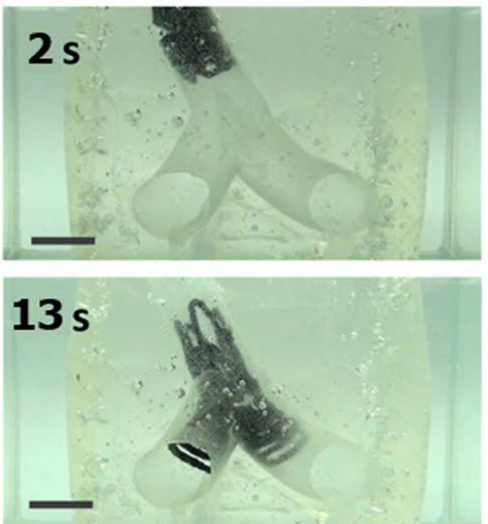

(c) Printed bifurcated stent

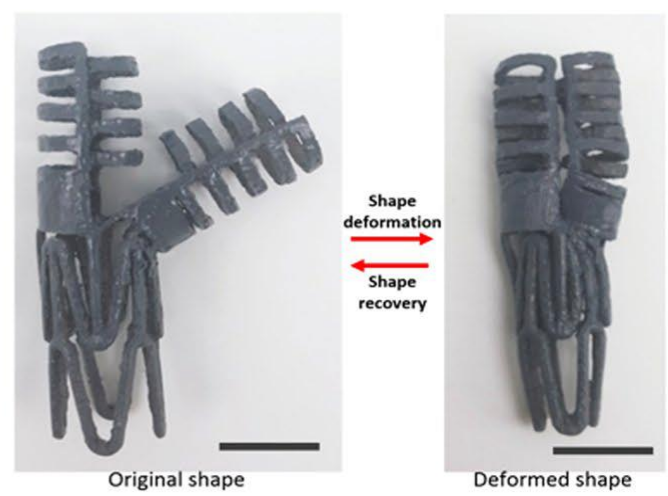

Recovery

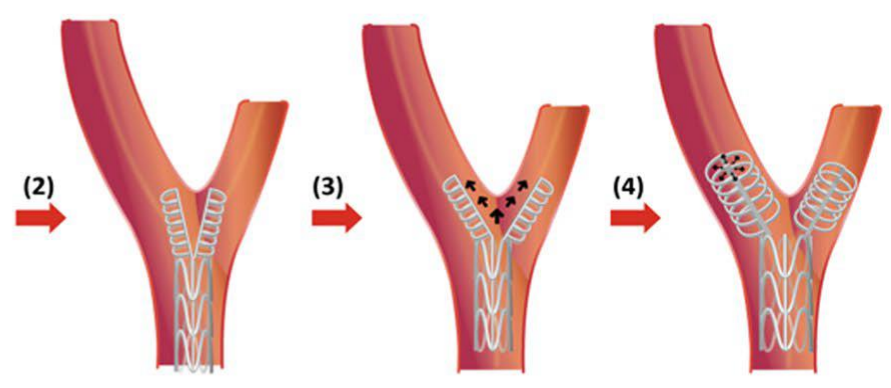

Figure 17. Development of bifurcated design of tubular stent and its deployment [93]. 
It is known that smart devices, used for biomedical application, can be prepared using shape memory polyurethane and its composites. However, with expanding knowledge, there is a growing need for advanced technologies such as additive manufacturing or 3D printing techniques for the development of smart devices and information carriers [97-100]. Several applications in the biomedical field require complex and personalized dimensions and shapes for smart devices which are difficult to produce using conventional manufacturing techniques. The combination of shape memory and $3 \mathrm{D}$ printing can be a solution which has enormous potential for the development of complex smart devices [98,101,102]. 3D printing is a low cost rapid fabrication technique with layer-by-layer additive manufacturing for the production of complex and personalized structures and devices. 3D printing of shape memory polyurethanes may need optimization of several parameters such as bulk density, dimensional accuracy, print orientation, infill percentage, surface roughness, etc., in order to produce the desired objects $[103,104]$. Several researchers worldwide are trying to use additive manufacturing technique for smart device development using shape memory polyurethane and its composites. In line with this, Zhang et. al. [105] have developed printable PCL based photothermal shape memory polyurethane and used it as an ink for 3D printing of different shapes and structures. They demonstrated the shape memory ability of 3D printed device along with its self-healing capability. Light beam was used as an external trigger to stimulate the shape memory and self-healing. They found more than $90 \%$ shape fixing ratio and shape recovery ratio along with $70 \%$ self-healing ability. PCL and PLA based polyurethane inks are also developed by other groups who demonstrated the shape memory ability of 3D printed objects [46,101].

\section{Author's Perspective on the Shape Memory Polyurethane Composites}

Our group has demonstrated the development of PCL based polyurethane composite with chitosan [106]. Chitosan has an advantage of antibacterial property along with the induction of bone formation and wound healing ability which is shadowed by the limitation of its processing temperature. Due to the overlapping of melting temperature and thermal degradation temperature, chitosan cannot be thermally processed along with other polymers in order to fabricate composites. Therefore, dispersion or blending of chitosan in polymer matrix is always a challenging task. In this regard, our group has made efforts to homogenously disperse chitosan into the polymers by in situ polymerization instead of blending chitosan with the polymer matrix. We have fabricated PCL based polyurethane by in situ polymerization in presence of micro-to-nano sized chitosan. The advantage of using nano sized chitosan is that it provides several hydroxyl groups to react with isocyanate resulting in the formation of urethane bonds which lead to homogeneous dispersion and interfacial adhesion of nano chitosan in polymer matrix. We have found that the presence of chitosan in polyurethane matrix acts as crosslinking point in the polymer matrix which possibly enhances the mechanical property along with thermo-responsive shape memory ability of the composite (Figure 18). The use of chitosan as a filler in polyurethane matrix provides opportunities for developing polymers with tailored properties. The presence of chitosan in polyurethane matrix enhances the applicability of the polyurethane in several biomedical domains such as medical bandage development, bone tissue engineering, self-healing, implants development, etc. 


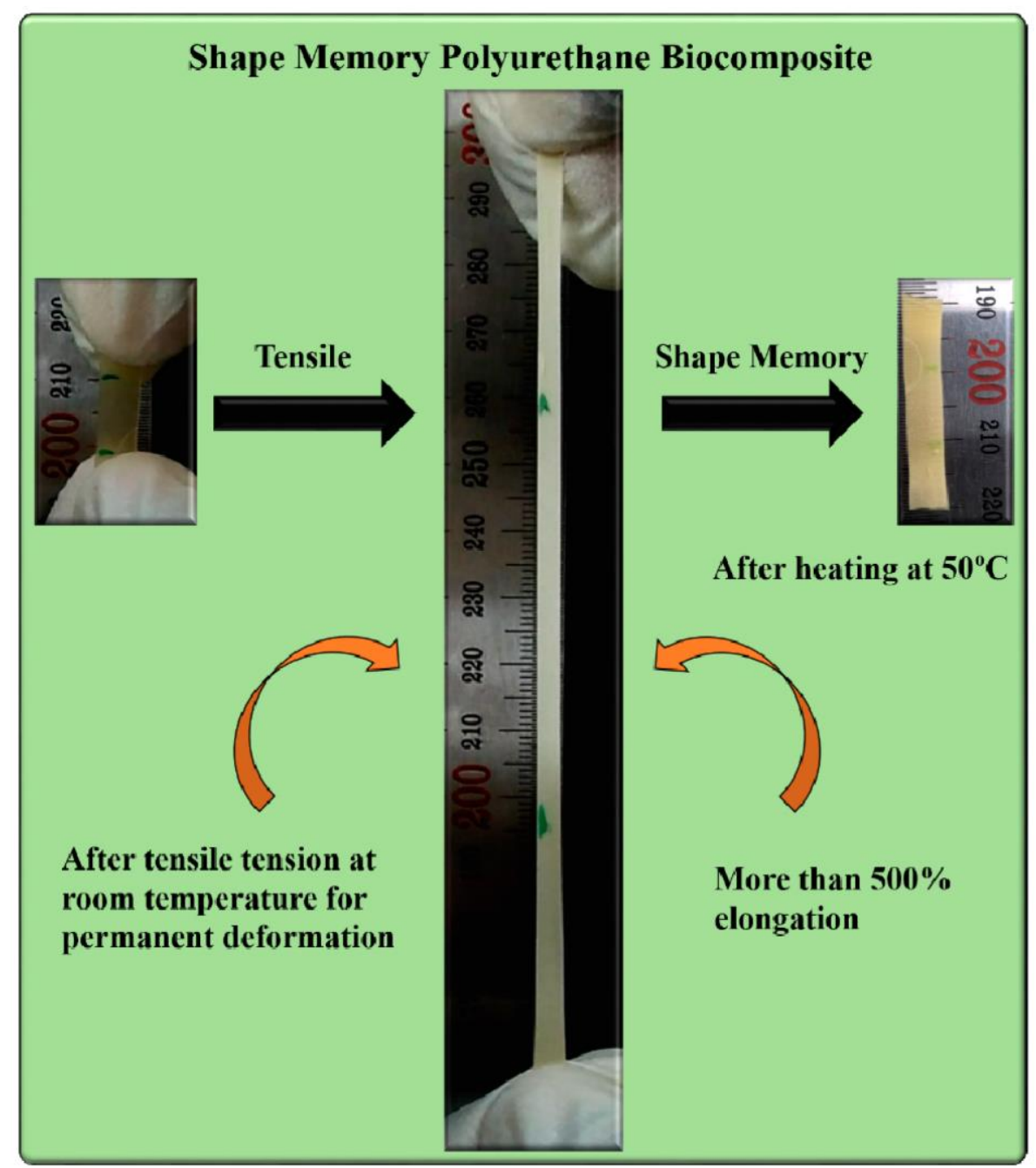

Figure 18. Demonstration of the shape memory ability of PCL based polyurethane chitosan composite [106].

Due to the presence of chitosan, biodegradable polymer such as polycaprolactone (PCL) based SMP composites can be used for several applications. As described in the previous section, every application is based on some specific essential properties. In order to develop the medical pressure bandage, shape memory of the polyurethane is the key property which generates the required pressure. The same can be tuned by adjusting the amount of chitosan in the polymer matrix. The usability of the pressure bandage made of PCL based polyurethane chitosan composite can be enhanced by the incorporation of essential drug into polyurethane matrix which will be delivered as and when required for wound treatment.

Similarly, PCL based polyurethane chitosan composite can be used for bone tissue engineering as discussed in the previous section. Utilization of swelling ability and bone formation induction ability of chitosan along with shape memory ability of PCL polyurethane synchronously may result in an effective formulation for bone healing application. The addition of a required healing drug in the polymer matrix can enhance the applicability of the polyurethane chitosan composites.

The effective use of PCL based SMP chitosan composite can be demonstrated in the production of cardiovascular implants. Polyurethane chitosan composite along with a deliverable drug can be thermally processed to stents or scaffold using 3D printing or other techniques. The developed stent may attain the shape memory ability together with drug delivery system which are the key properties required for the development of temporary self-expanded stents. The known rate of degradation of the polymers and fillers may help in the prediction of the working age of a temporary self-expandable stent after injection in the vein and thus, reducing the chances of secondary surgery. 
The above discussion shows the significance of incorporation of fillers into the polyurethane matrix for intended applications. Materials like chitosan can enhance the usefulness of the polyurethanes in several biomedical applications. Likewise, other fillers such as lignin, carbon-based fillers, metals, hydroxyapatite, bioactive glass, and other organic or inorganic fillers can also be incorporated in the polymer matrix for better applicability of biodegradable SMP for targeted applications.

\section{Summary}

The use of SMPs and their composites in a wide range of different applications show the versatile nature and importance of this material. It is not far from being accepted for use in clinical applications. Applications such as self-healing, bandages, implants, etc., need validations with real conditions which is a costly and time-consuming process. Moreover, the biocompatibility and biodegradability of these materials in stipulated time along with desired shape memory properties are key factors in order to be applicable in mentioned areas. However, it can be confirmed that SMPs and their composites may be regarded as fascinating materials and potential candidates for several biomedical and engineering applications. We believe that the research and exploration in designing SMP and its composites with multidimensional aspects will grow further and contribute to human health along with the environment.

Author Contributions: A.G. proposed ideas and wrote the first draft. A.M. prepared the tables. B.S.K. reviewed and revised paper. All authors read and approved the final version of the manuscript.

Funding: This work was supported by Post-Doctoral Fellowship Program funded by the Ministry of Education of the Republic of Korea through the Chungbuk National University in 2019-2020.

Conflicts of Interest: The authors declare no conflicts of interest.

\section{References}

1. Liu, C.; Qin, H.; Mather, P.T. Review of progress in shape-memory polymers. J. Mater. Chem. 2007, 17, 1543-1558. [CrossRef]

2. Yang, Q.; Zheng, W.; Zhao, W.; Peng, C.; Ren, J.; Yu, Q.; Hu, Y.; Zhang, X. One-way and two-way shape memory effects of a high-strain cis-1,4-polybutadiene-polyethylene copolymer based dynamic network via self-complementary quadruple hydrogen bonding. Polym. Chem. 2019, 10, 718-726. [CrossRef]

3. Ware, T.; Hearon, K.; Lonnecker, A.; Wooley, K.L.; Maitland, D.J.; Voit, W. Triple-Shape Memory Polymers Based on Self-Complementary Hydrogen Bonding. Macromolecules 2012, 45, 1062-1069. [CrossRef] [PubMed]

4. Xian, J.; Geng, J.; Wang, Y.; Xia, L. Quadruple-shape-memory effect of TPI/LDPE/HDPE composites. Polym. Adv. Technol. 2018, 29, 982-988. [CrossRef]

5. Bothe, M.; Pretsch, T. Bidirectional actuation of a thermoplastic polyurethane elastomer. J. Mater. Chem. A 2013, 1, 14491-14497. [CrossRef]

6. Goo, N.S.; Paik, I.H.; Yoon, K.J. The durability of a conducting shape memory polyurethane actuator. Smart Mater. Struct. 2007, 16, N23-N26. [CrossRef]

7. Tobushi, H.; Hayashi, S.; Kojima, S. Mechanical Properties of Shape Memory Polymer of Polyurethane Series: Basic Characteristics of Stress-Strain-Temperature Relationship. Jsme Int. J. Ser. 1 Solid Mech. Strength Mater. 1992, 35, 296-302.

8. Tobushi, H.; Hara, H.; Yamada, E.; Hayashi, S. Thermomechanical properties in a thin film of shape memory polymer of polyurethane series. Smart Mater. Struct. 1996, 5, 483-491. [CrossRef]

9. Meng, Q.; Hu, J. A review of shape memory polymer composites and blends. Compos. Part. A Appl. Sci. Manuf. 2009, 40, 1661-1672. [CrossRef]

10. Lendlein, A.; Gould, O.E.C. Reprogrammable recovery and actuation behaviour of shape-memory polymers. Nat. Rev. Mater. 2019, 4, 116-133. [CrossRef]

11. Thakur, S.; Hu, J. Polyurethane: A Shape Memory Polymer (SMP). In Aspects of Polyurethanes; Faris, Y., Ed.; IntechOpen: London, UK, 2017.

12. McCaig, C.D.; Song, B.; Rajnicek, A.M. Electrical dimensions in cell science. J. Cell Sci. 2009, 122, 4267-4276. [CrossRef] [PubMed] 
13. Oschman, J.L. Chapter 16-The Electromagnetic Environment. In Energy Medicine (Second Edition); Oschman, J.L., Ed.; Churchill Livingstone: Edinburgh, UK, 2016; pp. 269-295.

14. Taki, M.; Watanabe, S. Biological and health effects of exposure to electromagnetic field from mobile communications systems. Iatss Res. 2001, 25, 40-50. [CrossRef]

15. Liu, C.; Wang, X.; Huang, X.; Liao, X.; Shi, B. Absorption and Reflection Contributions to the High Performance of Electromagnetic Waves Shielding Materials Fabricated by Compositing Leather Matrix with Metal Nanoparticles. ACS Appl. Mater. Interfaces 2018, 10, 14036-14044. [CrossRef] [PubMed]

16. Kong, L.; Yin, X.; Zhang, Y.; Yuan, X.; Li, Q.; Ye, F.; Cheng, L.; Zhang, L. Electromagnetic Wave Absorption Properties of Reduced Graphene Oxide Modified by Maghemite Colloidal Nanoparticle Clusters. J. Phys. Chem. C 2013, 117, 19701-19711. [CrossRef]

17. Mishra, R. Specific functional properties of 3D woven glass nanocomposites. J. Compos. Mater. 2014, 48, 1745-1754. [CrossRef]

18. Jin, X.; Ni, Q.-Q.; Natsuki, T. Composites of multi-walled carbon nanotubes and shape memory polyurethane for electromagnetic interference shielding. J. Compos. Mater. 2011, 45, 2547-2554. [CrossRef]

19. Wong, E.W.; Sheehan, P.E.; Lieber, C.M. Nanobeam Mechanics: Elasticity, Strength, and Toughness of Nanorods and Nanotubes. Science 1997, 277, 1971-1975. [CrossRef]

20. Menon, A.V.; Madras, G.; Bose, S. Shape memory polyurethane nanocomposites with porous architectures for enhanced microwave shielding. Chem. Eng. J. 2018, 352, 590-600. [CrossRef]

21. Lamberti, P.; Kuzhir, P.; Tucci, V. A robust approach to the design of an electromagnetic shield based on pyrolitic carbon. Aip Adv. 2016, 6, 075301. [CrossRef]

22. Yan, Y.; Xia, H.; Qiu, Y.; Xu, Z.; Ni, Q.-Q. Shape memory driving thickness-adjustable G@SMPU sponge with ultrahigh carbon loading ratio for excellent microwave shielding performance. Mater. Lett. 2019, 236, 116-119. [CrossRef]

23. Suarato, G.; Bertorelli, R.; Athanassiou, A. Borrowing from Nature: Biopolymers and Biocomposites as Smart Wound Care Materials. Front. Bioeng. Biotechnol. 2018, 6, 137. [CrossRef] [PubMed]

24. Eming, S.A.; Koch, M.; Krieger, A.; Brachvogel, B.; Kreft, S. Differential Proteomic Analysis Distinguishes Tissue Repair Biomarker Signatures in Wound Exudates Obtained from Normal Healing and Chronic Wounds. J. Proteome Res. 2010, 9, 4758-4766. [CrossRef] [PubMed]

25. Agale, S.V. Chronic Leg Ulcers: Epidemiology, Aetiopathogenesis, and Management. Ulcers 2013, 2013 , 9. [CrossRef]

26. De La Brassinne, M.; Thirion, L.; Horvat, L.-I. A novel method of comparing the healing properties of two hydrogels in chronic leg ulcers. J. Eur. Acad. Dermatol. Venereol. 2006, 20, 131-135. [CrossRef]

27. O'Meara, S.; Cullum, N.; Nelson, E.A.; Dumville, J.C. Compression for venous leg ulcers. Cochrane Database Syst. Rev. 2012, 11, CD000265. [CrossRef]

28. Hladky, S.B.; Barrand, M.A. Mechanisms of fluid movement into, through and out of the brain: Evaluation of the evidence. Fluids Barriers Cns 2014, 11, 26. [CrossRef]

29. Hettrick, H. The science of compression therapy for chronic venous insufficiency edema. J. Am. Coll. Certif. Wound Spec. 2009, 1, 20-24. [CrossRef]

30. Ahmad, M.; Luo, J.; Miraftab, M. Feasibility study of polyurethane shape-memory polymer actuators for pressure bandage application. Sci. Technol. Adv. Mater. 2012, 13, 015006. [CrossRef]

31. Sáenz-Pérez, M.; Bashir, T.; Laza, J.M.; García-Barrasa, J.; Vilas, J.L.; Skrifvars, M.; León, L.M. Novel shape-memory polyurethane fibers for textile applications. Text. Res. J. 2019, 89, 1027-1037. [CrossRef]

32. Jahid, M.A.; Hu, J.; Wong, K.; Wu, Y.; Zhu, Y.; Sheng Luo, H.H.; Zhongmin, D. Fabric Coated with Shape Memory Polyurethane and Its Properties. Polymers 2018, 10, 681. [CrossRef]

33. Liu, Y.; Chung, A.; Hu, J.; Lv, J. Shape memory behavior of SMPU knitted fabric. J. Zhejiang Univ.-Sci. A 2007, 8, 830-834. [CrossRef]

34. Narayana, H.; Hu, J.; Kumar, B.; Shang, S.; Ying, M.; Young, R.J. Designing of advanced smart medical stocking using stress-memory polymeric filaments for pressure control and massaging. Mater. Sci. Eng. C 2018, 91, 263-273. [CrossRef] [PubMed]

35. Wnek, G.E.; Carr, M.E.; Simpson, D.G.; Bowlin, G.L. Electrospinning of Nanofiber Fibrinogen Structures. Nano Lett. 2003, 3, 213-216. [CrossRef]

36. Guerado, E.; Caso, E. Challenges of bone tissue engineering in orthopaedic patients. World J. Orthop. 2017, 8, 87-98. [CrossRef] [PubMed] 
37. Ghassemi, T.; Shahroodi, A.; Ebrahimzadeh, M.H.; Mousavian, A.; Movaffagh, J.; Moradi, A. Current Concepts in Scaffolding for Bone Tissue Engineering. Arch. Bone Jt. Surg. 2018, 6, 90-99. [PubMed]

38. Mulchandani, N.; Gupta, A.; Katiyar, V. Polylactic Acid Based Hydrogels and Its Renewable Characters: Tissue Engineering Applications. In Cellulose-Based Superabsorbent Hydrogels; Mondal, M.I.H., Ed.; Springer International Publishing: Cham, Switzerland, 2018; pp. 1-24.

39. Cortizo, M.S.; Belluzo, M.S. Biodegradable Polymers for Bone Tissue Engineering. In Industrial Applications of Renewable Biomass Products: Past, Present and Future; Goyanes, S.N., D'Accorso, N.B., Eds.; Springer International Publishing: Cham, Switzerland, 2017; pp. 47-74.

40. Kashirina, A.; Yao, Y.; Liu, Y.; Leng, J. Biopolymers as bone substitutes: A review. Biomater. Sci. 2019, 7, 3961-3983. [CrossRef]

41. Zhang, Y.; Hu, J.; Zhao, X.; Xie, R.; Qin, T.; Ji, F. Mechanically Robust Shape Memory Polyurethane Nanocomposites for Minimally Invasive Bone Repair. ACS Appl. Bio Mater. 2019, 2, 1056-1065. [CrossRef]

42. Correia, C.O.; Mano, J.F. Chitosan scaffolds with a shape memory effect induced by hydration. J. Mater. Chem. B 2014, 2, 3315-3323. [CrossRef]

43. Correia, C.O.; Leite, Á.J.; Mano, J.F. Chitosan/bioactive glass nanoparticles scaffolds with shape memory properties. Carbohydr. Polym. 2015, 123, 39-45. [CrossRef]

44. Leite, Á.J.; Caridade, S.G.; Mano, J.F. Synthesis and characterization of bioactive biodegradable chitosan composite spheres with shape memory capability. J. Non-Cryst. Solids 2016, 432, 158-166. [CrossRef]

45. Gupta, A.K.; Gupta, M. Synthesis and surface engineering of iron oxide nanoparticles for biomedical applications. Biomaterials 2005, 26, 3995-4021. [CrossRef] [PubMed]

46. Wang, Y.-J.; Jeng, U.S.; Hsu, S.-h. Biodegradable Water-Based Polyurethane Shape Memory Elastomers for Bone Tissue Engineering. ACS Biomater. Sci. Eng. 2018, 4, 1397-1406. [CrossRef]

47. Wang, Q.; Chen, B.; Cao, M.; Sun, J.; Wu, H.; Zhao, P.; Xing, J.; Yang, Y.; Zhang, X.; Ji, M.; et al. Response of MAPK pathway to iron oxide nanoparticles in vitro treatment promotes osteogenic differentiation of hBMSCs. Biomaterials 2016, 86, 11-20. [CrossRef] [PubMed]

48. Xie, R.; Hu, J.; Hoffmann, O.; Zhang, Y.; Ng, F.; Qin, T.; Guo, X. Self-fitting shape memory polymer foam inducing bone regeneration: A rabbit femoral defect study. Biochim. Et Biophys. Acta (Bba)-Gen. Subj. 2018, 1862, 936-945. [CrossRef] [PubMed]

49. Villa, M.M.; Wang, L.; Huang, J.; Rowe, D.W.; Wei, M. Bone tissue engineering with a collagen-hydroxyapatite scaffold and culture expanded bone marrow stromal cells. J. Biomed. Mater. Res. Part. B Appl. Biomater. 2015, 103, 243-253. [CrossRef] [PubMed]

50. Zhou, H.; Lee, J. Nanoscale hydroxyapatite particles for bone tissue engineering. Acta Biomater. 2011, 7 , 2769-2781. [CrossRef] [PubMed]

51. Yoshikawa, H.; Myoui, A. Bone tissue engineering with porous hydroxyapatite ceramics. J. Artif. Organs 2005, 8, 131-136. [CrossRef]

52. Zhang, P.; Li, G. Advances in healing-on-demand polymers and polymer composites. Progress Polym. Sci. 2016, 57, 32-63. [CrossRef]

53. Jackson, A.C.; Bartelt, J.A.; Braun, P.V. Transparent Self-Healing Polymers Based on Encapsulated Plasticizers in a Thermoplastic Matrix. Adv. Funct. Mater. 2011, 21, 4705-4711. [CrossRef]

54. Nakahata, M.; Takashima, Y.; Yamaguchi, H.; Harada, A. Redox-responsive self-healing materials formed from host-guest polymers. Nat. Commun. 2011, 2, 511. [CrossRef]

55. Takashima, Y.; Harada, A. Self-Healing Polymers. In Encyclopedia of Polymeric Nanomaterials; Kobayashi, S., Müllen, K., Eds.; Springer: Berlin/Heidelberg, Germany, 2015; pp. 2209-2214.

56. Chakma, P.; Konkolewicz, D. Dynamic Covalent Bonds in Polymeric Materials. Angew. Chem. Int. Ed. 2019, 58, 9682-9695. [CrossRef] [PubMed]

57. Aïssa, B.; Therriault, D.; Haddad, E.; Jamroz, W. Self-Healing Materials Systems: Overview of Major Approaches and Recent Developed Technologies. Adv. Mater. Sci. Eng. 2012, 2012, 17. [CrossRef]

58. Zhu, D.Y.; Rong, M.Z.; Zhang, M.Q. Self-healing polymeric materials based on microencapsulated healing agents: From design to preparation. Prog. Polym. Sci. 2015, 49, 175-220. [CrossRef]

59. Fan, W.; Li, W.; Zhang, Y.; Wang, W.; Zhang, X.; Song, L.; Liu, X. Cooperative self-healing performance of shape memory polyurethane and Alodine-containing microcapsules. RSC Adv. 2017, 7, 46778-46787. [CrossRef] 
60. Yan, P.; Zhao, W.; Fu, X.; Liu, Z.; Kong, W.; Zhou, C.; Lei, J. Multifunctional polyurethane-vitrimers completely based on transcarbamoylation of carbamates: Thermally-induced dual-shape memory effect and self-welding. RSC Adv. 2017, 7, 26858-26866. [CrossRef]

61. Xu, Y.; Chen, D. Shape memory-assisted self-healing polyurethane inspired by a suture technique. J. Mater. Sci. 2018, 53, 10582-10592. [CrossRef]

62. Wen, H.; Chen, S.; Ge, Z.; Zhuo, H.; Ling, J.; Liu, Q. Development of humidity-responsive self-healing zwitterionic polyurethanes for renewable shape memory applications. RSC Adv. 2017, 7, 31525-31534. [CrossRef]

63. González-García, Y.; Mol, J.M.C.; Muselle, T.; De Graeve, I.; Van Assche, G.; Scheltjens, G.; Van Mele, B.; Terryn, H. A combined mechanical, microscopic and local electrochemical evaluation of self-healing properties of shape-memory polyurethane coatings. Electrochim. Acta 2011, 56, 9619-9626. [CrossRef]

64. Ghosh, T.; Karak, N. Tough interpenetrating polymer network of silicone containing polyurethane and polystyrene with self-healing, shape memory and self-cleaning attributes. Rsc Adv. 2018, 8, 17044-17055. [CrossRef]

65. Fan, L.F.; Rong, M.Z.; Zhang, M.Q.; Chen, X.D. Repeated Intrinsic Self-Healing of Wider Cracks in Polymer via Dynamic Reversible Covalent Bonding Molecularly Combined with a Two-Way Shape Memory Effect. Acs Appl. Mater. Interfaces 2018, 10, 38538-38546. [CrossRef]

66. Ban, J.; Zhu, L.; Chen, S.; Wang, Y. The Effect of 4-Octyldecyloxybenzoic Acid on Liquid-Crystalline Polyurethane Composites with Triple-Shape Memory and Self-Healing Properties. Materials 2016, 9, 792. [CrossRef] [PubMed]

67. Chen, S.; Mo, F.; Yang, Y.; Stadler, F.J.; Chen, S.; Yang, H.; Ge, Z. Development of zwitterionic polyurethanes with multi-shape memory effects and self-healing properties. J. Mater. Chem. A 2015, 3, 2924-2933. [CrossRef]

68. Chen, W.; Zhou, Y.; Li, Y.; Sun, J.; Pan, X.; Yu, Q.; Zhou, N.; Zhang, Z.; Zhu, X. Shape-memory and self-healing polyurethanes based on cyclic poly ( $\varepsilon$-caprolactone). Polym. Chem. 2016, 7, 6789-6797. [CrossRef]

69. Deng, X.-Y.; Xie, H.; Du, L.; Fan, C.-J.; Cheng, C.-Y.; Yang, K.-K.; Wang, Y.-Z. Polyurethane networks based on disulfide bonds: From tunable multi-shape memory effects to simultaneous self-healing. Sci. China Mater. 2019, 62, 437. [CrossRef]

70. Du, W.; Jin, Y.; Lai, S.; Shi, L.; Fan, W.; Pan, J. Near-infrared light triggered shape memory and self-healable polyurethane/functionalized graphene oxide composites containing diselenide bonds. Polymer 2018, 158, 120-129. [CrossRef]

71. Xu, Y.; Chen, D. Self-healing thermoplastic polyurethane (TPU)/polycaprolactone (PCL) /multi-wall carbon nanotubes (MWCNTs) blend as shape-memory composites. Compos. Sci. Technol. 2018, 168, $255-262$. [CrossRef]

72. Montarnal, D.; Capelot, M.; Tournilhac, F.; Leibler, L. Silica-Like Malleable Materials from Permanent Organic Networks. Science 2011, 334, 965-968. [CrossRef]

73. Brutman, J.P.; Delgado, P.A.; Hillmyer, M.A. Polylactide Vitrimers. ACS Macro Lett. 2014, 3, 607-610. [CrossRef]

74. Yuan, C.e.; Rong, M.Z.; Zhang, M.Q.; Zhang, Z.P.; Yuan, Y.C. Self-Healing of Polymers via Synchronous Covalent Bond Fission/Radical Recombination. Chem. Mater. 2011, 23, 5076-5081. [CrossRef]

75. Blackman, L.D.; Gunatillake, P.A.; Cass, P.; Locock, K.E.S. An introduction to zwitterionic polymer behavior and applications in solution and at surfaces. Chem. Soc. Rev. 2019, 48, 757-770. [CrossRef]

76. Zheng, L.; Sundaram, H.S.; Wei, Z.; Li, C.; Yuan, Z. Applications of zwitterionic polymers. React. Funct. Polym. 2017, 118, 51-61. [CrossRef]

77. Lowe, A.B.; McCormick, C.L. Synthesis and Solution Properties of Zwitterionic Polymers. Chem. Rev. 2002, 102, 4177-4190. [CrossRef] [PubMed]

78. Boccafoschi, F.; Fusaro, L.; Cannas, M. 15-Immobilization of peptides on cardiovascular stent. In Functionalised Cardiovascular Stents; Wall, J.G., Podbielska, H., Wawrzyńska, M., Eds.; Woodhead Publishing: Sawston, UK; Cambridge, UK, 2018; pp. 305-318.

79. Weems, A.C.; Boyle, A.J.; Maitland, D.J. Two-year performance study of porous, thermoset, shape memory polyurethanes intended for vascular medical devices. Smart Mater. Struct. 2017, 26, 035054. [CrossRef] [PubMed] 
80. Weems, A.C.; Wacker, K.T.; Carrow, J.K.; Boyle, A.J.; Maitland, D.J. Shape memory polyurethanes with oxidation-induced degradation: In vivo and in vitro correlations for endovascular material applications. Acta Biomaterialia 2017, 59, 33-44. [CrossRef] [PubMed]

81. Singh, C.; Wong, C.S.; Wang, X. Medical Textiles as Vascular Implants and Their Success to Mimic Natural Arteries. J. Funct. Biomater. 2015, 6, 500-525. [CrossRef]

82. Bussooa, A.; Neale, S.; Mercer, J.R. Future of Smart Cardiovascular Implants. Sensors 2018, 18, 2008. [CrossRef]

83. Stoeckel, D.; Pelton, A.; Duerig, T. Self-expanding nitinol stents: Material and design considerations. Eur. Radiol. 2004, 14, 292-301. [CrossRef]

84. Cui, C. 8-Biocompatibility and fabrication of in situ bioceramic coating/titanium alloy biocomposites. In Metals for Biomedical Devices; Niinomi, M., Ed.; Woodhead Publishing: Sawston, UK; Cambridge, UK, 2010; pp. 202-232.

85. Zheng, Y.; Dong, R.; Shen, J.; Guo, S. Tunable Shape Memory Performances via Multilayer Assembly of Thermoplastic Polyurethane and Polycaprolactone. ACS Appl. Mater. Interfaces 2016, 8, 1371-1380. [CrossRef]

86. Wache, H.M.; Tartakowska, D.J. Development of a polymer stent with shape memory effect as a drug delivery system. J. Mater. Sci. Mater. Med. 2003, 14, 109-112. [CrossRef]

87. Ahmad Zubir, S.; Mat Saad, N.; Harun, F.W.; Ali, E.S.; Ahmad, S. Incorporation of palm oil polyol in shape memory polyurethane: Implication for development of cardiovascular stent. Polym. Adv. Technol. 2018, 29, 2926-2935. [CrossRef]

88. Gu, S.-Y.; Chang, K.; Jin, S.-P. A dual-induced self-expandable stent based on biodegradable shape memory polyurethane nanocomposites (PCLAU/Fe3O4) triggered around body temperature. J. Appl. Polym. Sci. 2018, 135, 45686. [CrossRef]

89. Wang, Z.; Hou, Z.; Wang, Y. Fluorinated waterborne shape memory polyurethane urea for potential medical implant application. J. Appl. Polym. Sci. 2013, 127, 710-716. [CrossRef]

90. Baer, G.M.; Wilson, T.S.; Small, W.t.; Hartman, J.; Benett, W.J.; Matthews, D.L.; Maitland, D.J. Thermomechanical properties, collapse pressure, and expansion of shape memory polymer neurovascular stent prototypes. J. Biomed. Mater. Res. Part. B Appl. Biomater. 2009, 90, 421-429. [CrossRef] [PubMed]

91. Burke, A.; Hasirci, N. Polyurethanes in Biomedical Applications. In Biomaterials; Springer: Boston, MA, USA, 2004.

92. Ajili, S.H.; Ebrahimi, N.G.; Soleimani, M. Polyurethane/polycaprolactane blend with shape memory effect as a proposed material for cardiovascular implants. Acta Biomater. 2009, 5, 1519-1530. [CrossRef]

93. Kim, T.; Lee, Y.-G. Shape transformable bifurcated stents. Sci. Rep. 2018, 8, 13911. [CrossRef]

94. Kuribayashi, K.; Tsuchiya, K.; You, Z.; Tomus, D.; Umemoto, M.; Ito, T.; Sasaki, M. Self-deployable origami stent grafts as a biomedical application of Ni-rich TiNi shape memory alloy foil. Mater. Sci. Eng. A 2006, 419, 131-137. [CrossRef]

95. Shyu, T.C.; Damasceno, P.F.; Dodd, P.M.; Lamoureux, A.; Xu, L.; Shlian, M.; Shtein, M.; Glotzer, S.C.; Kotov, N.A. A kirigami approach to engineering elasticity in nanocomposites through patterned defects. Nat. Mater. 2015, 14, 785. [CrossRef]

96. Neville, R.M.; Scarpa, F.; Pirrera, A. Shape morphing Kirigami mechanical metamaterials. Sci. Rep. 2016, 6, 31067. [CrossRef]

97. Chalissery, D.; Pretsch, T.; Staub, S.; Andrä, H. Additive Manufacturing of Information Carriers Based on Shape Memory Polyester Urethane. Polymers 2019, 11, 1005. [CrossRef]

98. Raasch, J.; Ivey, M.; Aldrich, D.; Nobes, D.S.; Ayranci, C. Characterization of polyurethane shape memory polymer processed by material extrusion additive manufacturing. Addit. Manuf. 2015, 8, 132-141. [CrossRef]

99. Pretsch, T.; Ecker, M.; Schildhauer, M.; Maskos, M. Switchable information carriers based on shape memory polymer. J. Mater. Chem. 2012, 22, 7757-7766. [CrossRef]

100. Li, W.; Liu, Y.; Leng, J. Programmable and Shape-Memorizing Information Carriers. Acs Appl. Mater. Interfaces 2017, 9, 44792-44798. [CrossRef] [PubMed]

101. Yang, H.; Leow, W.R.; Wang, T.; Wang, J.; Yu, J.; He, K.; Qi, D.; Wan, C.; Chen, X. 3D Printed Photoresponsive Devices Based on Shape Memory Composites. Adv. Mater. 2017, 29, 1701627. [CrossRef] [PubMed]

102. Bi, H.; Xu, M.; Ye, G.; Guo, R.; Cai, L.; Ren, Z. Mechanical, Thermal, and Shape Memory Properties of Three-Dimensional Printing Biomass Composites. Polymers 2018, 10, 1234. [CrossRef]

103. Yang, Y.; Chen, Y.; Wei, Y.; Li, Y. 3D printing of shape memory polymer for functional part fabrication. Int. J. Adv. Manuf. Technol. 2016, 84, 2079-2095. [CrossRef] 
104. Villacres, J. Additive manufacturing of shape memory polymers: Effects of print orientation and infill percentage on mechanical properties. Rapid Prototyp. J. 2018, 24, 744-751. [CrossRef]

105. Zhang, Y.; Yin, X.-Y.; Zheng, M.; Moorlag, C.; Yang, J.; Wang, Z.L. 3D printing of thermoreversible polyurethanes with targeted shape memory and precise in situ self-healing properties. J. Mater. Chem. A 2019, 7, 6972-6984. [CrossRef]

106. Gupta, A.; Kim, B.S. Shape Memory Polyurethane Biocomposites Based on Toughened Polycaprolactone Promoted by Nano-Chitosan. Nanomaterials 2019, 9, 225. [CrossRef] 